\title{
Heritage of (non-)existing cities \\ - on the Polish examples of medieval Świecie and Renaissance Krasiczyn
}

\author{
Karolina Zimna-Kawecka - Dominika Kuśnierz-Krupa - Michał Krupa
}

\author{
Dr Karolina Zimna-Kawecka, PhD \\ Nicolaus Copernicus University \\ Faculty of Fine Arts \\ Department of Art Conservation \\ ul. Sienkiewicza 30/32 \\ 87-100 Toruń \\ Poland \\ e-mail:kzimka@umk.pl \\ ORCID: 0000-0002-9612-8038
}

Prof. dr hab. inż. arch. Dominika Kuśnierz-Krupa

Cracow University of Technology

Faculty of Architecture

Chair of History of Architecture and Monument Preservation

ul. Podchorażzych 1

30-084 Cracow

Poland

e-mail: dkusnierz-krupa@pk.edu.pl

ORCID: 0000-0003-1678-4746

Dr hab. inż. arch. Michał Krupa, Assoc. Prof.

Cracow University of Technology

Faculty of Architecture

Chair of Housing Environment

ul. Podchorążych 1

30-084 Cracow

Poland

e-mail: michal.krupa@pk.edu.pl

ORCID: 0000-0002-2199-0598

Muzeológia a kultúrne dedičstvo, 2021, 9:3:65-92

DOI: $10.46284 / \mathrm{mkd} .2021 .9 .3 .4$

Heritage of (non-)existing cities - on the Polish examples of medieval Świecie and Renaissance Krasiczynn

This article analyses the urban heritage protection and spatial development policies of two model historical urban centres in Poland, whose spatial layout has been erased: medieval Świecie nad Wisła (the Pomeranian region) and Renaissance Krasiczyn (the Subcarpathian region). Their urban layouts had a significant compositional factor (a town and castle complex in axial plan). The second element important in terms of landscape protection and spatial planning is their history: at the end of the eighteenth century and during the nineteenth century they had to be relocated. The analysis covers the spatial form during the period of their founding, the reasons for transformation, their present-day state of preservation, and the current spatial conservation and development policy. General conservation conclusions have also been formulated.

Keywords: Świecie, Krasiczyn, urban layout, heritage, protection, revitalisation, Poland 
K. Zimna-Kawecka - D. Kuśnierz-Krupa - M. Krupa: Heritage of (non-)existing cities...

\section{Introduction and aim of the study}

The conservation of historic cities, which has a tradition that spans over a century, despite the evolution of its paradigms, has long been associated with planning. Such is the situation both in Poland and throughout Europe, where scientists and practitioners try to work out the best mechanisms for the heritage protection process. ${ }^{1}$

Polish heritage preservation law, aside from the heritage site registry itself, has empowered the local spatial development plan as a form of heritage protection which includes both buildings and, perhaps most importantly, areas. The Polish tradition of studying historic urban centres with the aim of formulating spatial and conservation policy dates back to the pre-war period, while the research projects of the 1950s and 1970s were an internationally recognised and shared model. In practice, the achievement of set goals fared much worse. The codification of the precepts of conserving and evaluating cities, when viewed internationally, dates back to the 1930s, when the two Athens Charters concerning heritage protection and urban planning were drafted. ${ }^{2}$ At present, historic cities are treated as an important component of the value of broadly understood material and intangible heritage and their protection is seen as a part of managing said heritage, as demonstrated by the UNESCO Recommendation on the Historic Urban Landscape of 2011 (hereafter referred to as the HUL Recommendation). ${ }^{3}$

The policy concerning the protection of urban heritage and the spatial development of urban centres, as a holistic vision, appears less complicated at first glance in the case of small or medium-sized cities and towns. However, it is these centres that, as a result of excessive, unplanned measures or neglect, are significantly altered and often lose the legibility of historical values arising from the traditional conveyors of these values: the compositional and spatial layout, panoramas, visual axes, building lines, and their character. ${ }^{4}$

The aim of this study is to prove the existence of a universality of conservation issues related to the preservation and highlighting of historic urban layouts in Poland. The question as to what type of conservation policy should be adopted — a conservative or revitalisation-

\footnotetext{
${ }^{1}$ HOSAGRAHAR, Jyoti. A History of Heritage Conservation in City Planning. In: The Routledge Handbook of Planning History, ed. HEIN, Carola, New York: Routledge, 2017, pp. 441-454; JANSSEN, Joks, LUITEN, Eric, RENES, Hans, ROUWENDAL, Jan. Heritage planning and spatial development in the Netherlands: changing policies and perspectives. In: International Journal of Heritage Studies, 20(1), 2014, pp. 1-21; RODWELL, Dennis. Managing Historic Cities. In: Journal of Architectural Conservation, 12(2), 2006, pp. 41-61; KUŚNIERZ-KRUPA, Dominika, KOBYLARCZYK, Justyna, LISIŃSKA-KUŚNIERZ, Małgorzata, KRUPA, Michał, KUŚNIERZ, Kazimierz. Typology of medieval urban layouts in historic Lesser Poland and their protection. In: Planning Perspectives, 36(4), 2021, pp. 847-857; DWORZECKI, Jacek, NOWICKA, Izabela, URBANEK, Andrzej, KWIATKOWSKI, Adam. Protection of national heritage in the light of the applicable law and the actions provided in this area by police in Poland. In: Muzeologia a kultúrne dedicstvo, 8(4), 2020, pp. 177-198.

${ }^{2}$ Karta Ateńska, Konferencja w Atenach 21-30 X 1931. In: SZMYGIN, Bogusław (ed.). Vademecum Konservatora Zabytków. Warsaw: Polski Komitet Narodowy ICOMOS, 2015, pp. 27-30.

${ }^{3}$ Zalecenia UNESCO w sprawie historycznego krajobrazu miejskiego, Paris, 2011. In: Vademecum..., pp. 183-189.

${ }^{4}$ KUŚNIERZ-KRUPA, Dominika. XIV-wieczne układy urbanistyczne w Matopolsce i na Podkarpaciu. Stan zachowania, ochrona i rewaloryzacja. Kraków: Wydawnictwo Politechniki Krakowskiej (further: WPK), 2019, pp. 10-50; KOBYLARCZYK, Justyna, KUŚNIERZ-KRUPA, Dominika. Jakość środowiska mieszkaniowego a dziedzictwo kulturowe na praykładzie mybranych miast wojewódz̨twa podkarpackiego. Kraków: WPK, 2018, pp. 5-80; MALIK, Rafał. Średniowieczne lokacje miejskie nad Dunajcem. Czchów. Ze studiów nad budową i kształtem miasta lokacyjnego. In: Wiadomości Konserwatorskie. Warszawa: Zarząd Główny Stowarzyszenia Konserwatorów Zabytków, 2008, pp. 67-73; MALIK, Rafał, Skała. Uwagi na temat budowy miasta średniowiecznego w świetle najnowszych badań nad wielkością i kształtem działki lokacyjnej. In: Wiadomości Konserwatorskie, 36, 2013, pp. 46-53; KUŚNIERZ-KRUPA, Dominika. Issue of protecting historic urban layouts of small towns in south-eastern Poland-on selected examples. In: IOP Conference Series: Materials Science and Engineering. IOP Publishing, 471, 2019, pp. 1-10.
} 


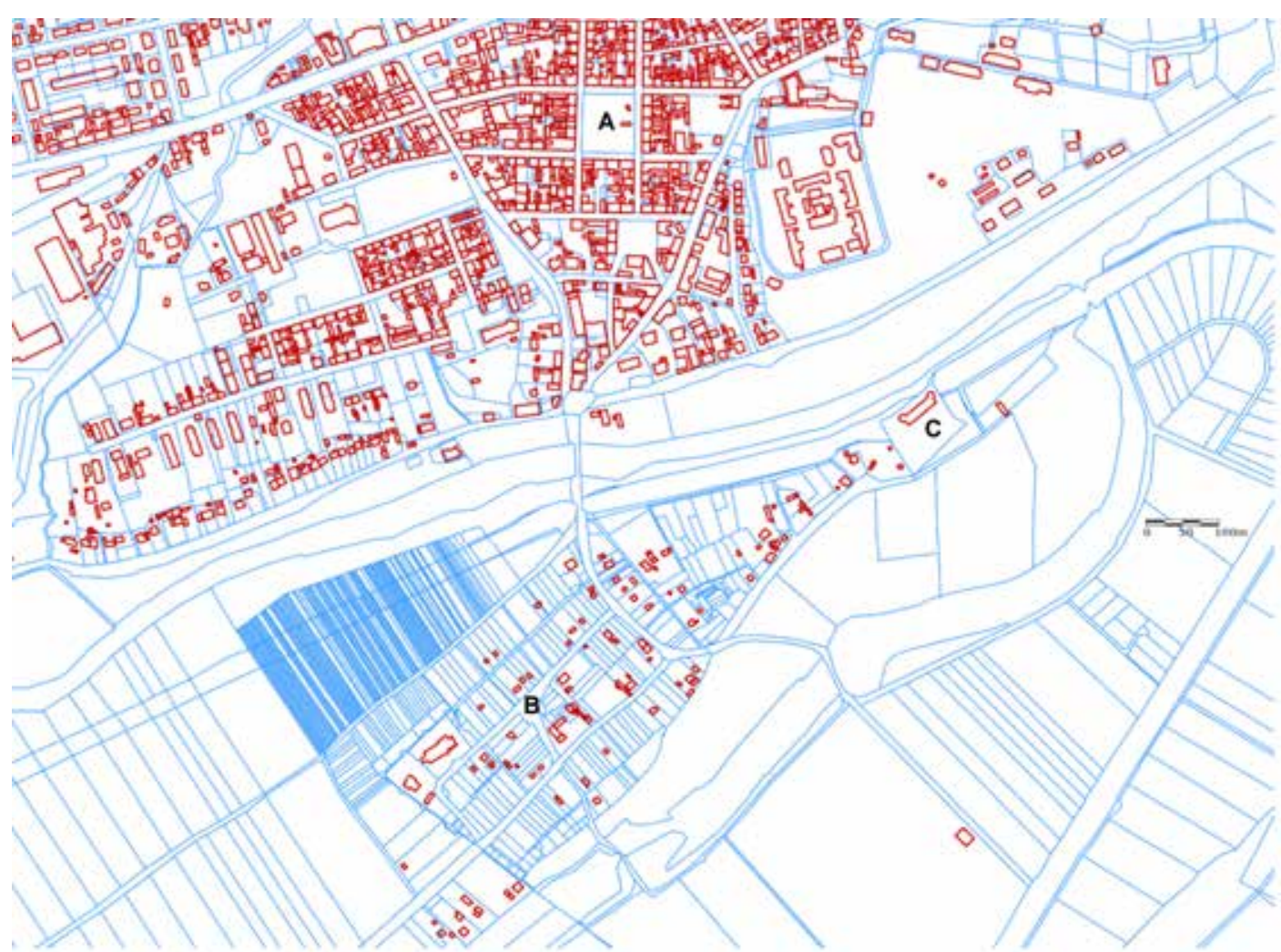

Fig. 1. Swiecie (Kuyavian-Pomeranian Voivodeship). Map of a part of the old and new town with the land cadastre. Legend: A - new town, B - old town, C - ruins of the Teutonic castle (source: https://mapy.geoportal. gov.pl/imap/Imgp_2.html?gpmap=gp1, 21.02.2020)

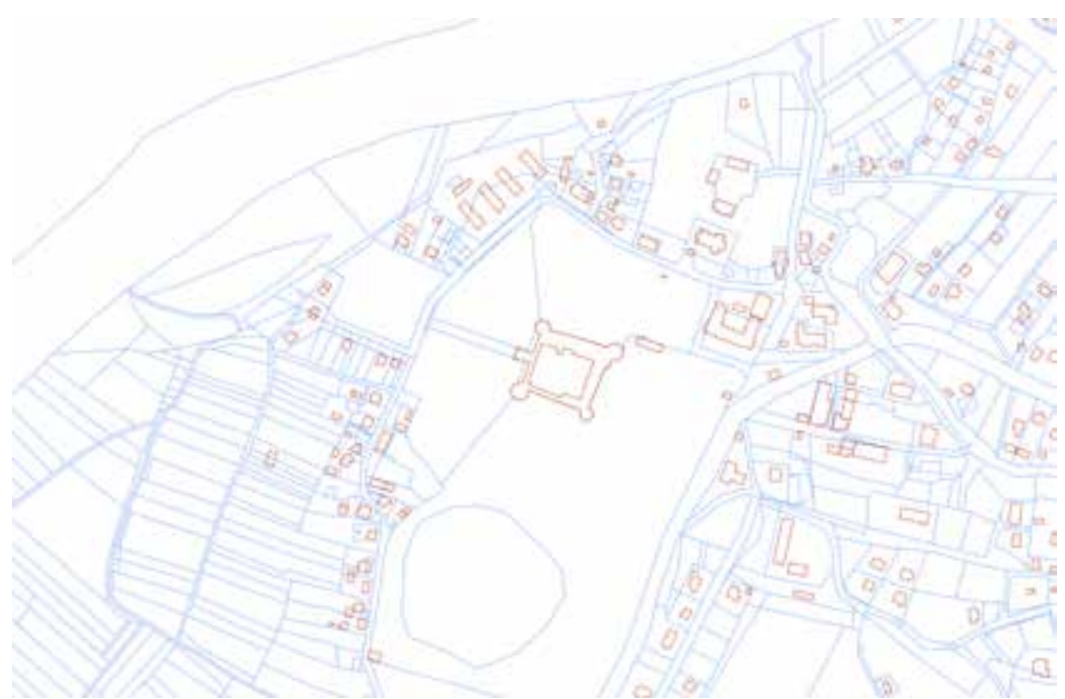

Fig. 2. Krasiçynn (Subcarpathian Voivodeship). Map of the historical urban layout of the residence and the town, with the land cadastre.

Legend: A - residence, $\mathrm{B}$ - area of the historic town, $\mathrm{C}$ - contemporary town centre (source: https://mapy.geoportal. gov.pl/imap/Imgp_2. html?gpmap $=g \mathrm{p} 0$, 06.03.2020)

oriented one-is essential from the point of view of heritage protection.

To this end, we chose two seemingly very different urban centres: the right-bank, medieval part of Świecie on the Vistula (in the Kuyavian-Pomeranian Voivodeship, Fig. 1) and Krasiczyn, a former urban-residential centre, which is now a rural commune (in the Voivodeship 
K. Zimna-Kawecka - D. Kuśnierz-Krupa - M. Krupa: Heritage of (non-)existing cities...

Podkarpackie, Fig. 2). Both towns, despite their different foundation periods-Świecie in the Middle Ages and Krasiczyn in the Renaissance-were laid out on a similar principle, i.e. the connection between the compositional city and the residence. Both historical cities have disappeared. However, the residences - the ruin of the castle in Świecie and the palace in Krasiczyn - remain, as well as the challenges related to the need for an appropriate policy, including conservation protection of the area containing these urban layouts of centres that do not exist today.

\section{Research method}

The two centres in question, located in areas quite distant from one another, were selected for study due to being examples of urban layouts that originally featured a high compositional factor from the period of the Middle Ages and the early modern period, which linked a town and a castle in their geometricised, axial plans. This factor is the key citygenic element under analysis from the perspective of heritage protection. The second element-highly interesting in terms of heritage and landscape protection, as well as spatial planning-is the peculiar history of both towns, which ceased to develop in the late eighteenth century and the early nineteenth century, and had to be relocated due to topographic factors. The results of this procedure were different for both centres_as relocated, Świecie nad Wisłą became a new, dynamically developing city, with a historical section that began to deteriorate and agrarianise while maintaining its castle ruins and parish church (partially rebuilt after the damage wrought during the Second World War). The relocation of Krasiczyn did not significantly improve its situation, as the new town had a rural character and the castle, still occupied by its owners, remained an important administrative centre. The historical layout itself was partially erased.

We therefore analysed and evaluated the circulatory and spatial forms of both towns during the period of their founding, the historical and topographic causes of their transformation, their current state of preservation, and their applicable spatial development and heritage protection policies. On this basis, we made an attempt at formulating general conservation guidelines for the protection and revitalisation of historical urban layouts.

\section{History and overview of the medieval urban layout of Świecie nad Wisła}

The territory where Świecie nad Wisłą was founded is located at the site where the Wda River flows into the Vistula River. On its northern side is a moraine elevation, while the strip between the two rivers forms a flood plain. Between the eleventh and the twelfth century, a gord was erected here, probably on the elevation. In 1198, a church was consecrated here, and the first written mention of the town's name was recorded-Zwece. ${ }^{5}$

In 1309, the territory, along with all of Vistula Pomerania, was annexed by the Order of Brothers of the German House of Saint Mary in Jerusalem-the Teutonic Knights. During this period, a crafting and trading settlement developed around the gord complex. The primary factors associated with the emergence of the town included a rise in its administrative (in 1320 Świecie became the seat of a Komturei-a commandery) and military (border centre) significance, in addition to its favourable location, which was economically important (near a major waterway - the Vistula — and close to a range of land routes). The site of the founding, on a flood plain, was also favourable in terms of defensibility.

\footnotetext{
${ }^{5}$ CZAJA, Roman (elab.). Atlas historyczny miast polskich, v. 1, Prusy Królewskie i Warmia, b. 6, Świecie. Toruń: Wydawnictwo Naukowe Uniwersytetu Mikołaja Kopernika, 2012, p. 7.
} 


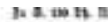

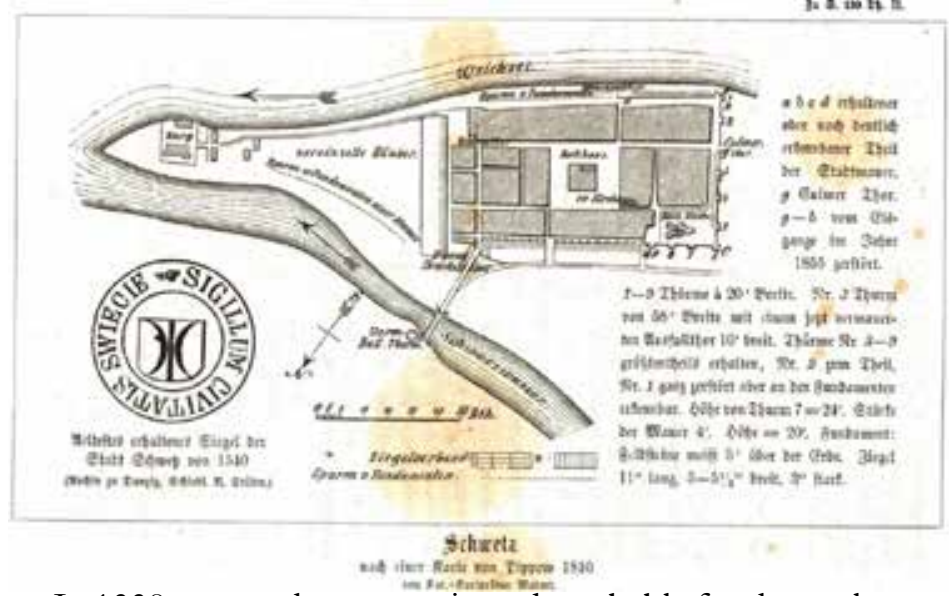

Fig. 3. Swiecie, old town layout by Pippow 1810 (source: Richard Wegner, Ein Pommersches Herzogthum und eine Deutsche Ordens-Komthurei: Kulturgeschichte des Schwetzer Kreises. Bd. 1, Tl. 2; Kulturgeschichte des Schwetzer Kreises, p. 130).

In 1338 a town charter was issued, probably for the settlement on the elevation. The decision to erect a massive masonry castle between the rivers, which was made around the same time, caused the first relocation of the town to the left bank of the Wda, where it was intended to form a defensive complex together with the castle. ${ }^{6}$

In 1375, Świecie nad Wisłą already functioned at its new site. It was founded in cruda radice and given a regular, grid-based plan, modelled after the plans of Silesian cities (Fig. 3, 4). ${ }^{7}$ The plan had a rectangular layout with a length of $350 \mathrm{~m}$ and a width of $125 \mathrm{~m}$, with its longer side oriented along the north-east-north-west axis. Its area was around 6 ha and was divided into



Fig. 4. Świecie, cadastral plan of 1886-1946 (source: Atlas Historyczny Miast Polskich: Świecie (Vol. I Prusy Królewskie i Warmia, book 6), historical elaboration by Roman Czaja, Cartographic elaboration: Radosław Golba, Zenon Kozieł, Agnieszka Pilarska; cooperation: Dariusz Chwiałkowski, Agnieszka Noryśkiewicz, Toruń 2012, fig. 1).

\footnotetext{
${ }^{6}$ Atlas..., p. 7.

${ }^{7}$ For more on Silesian cities, see: EYSYMONTT, Rafał. Kod genetyczny miasta. Średnionieczne miasta lokacyjne Dolnego Ślaske na tle urbanistyki Europejskiej. Wrocław: Via Nova, 2009, pp. 55-61, 617-632.
} 
K. Zimna-Kawecka - D. Kuśnierz-Krupa - M. Krupa: Heritage of (non-)existing cities...

around 140 plots inscribed into 12 urban blocks. The central block formed a market square measuring $90 \times 99 \mathrm{~m}$. The north-western corner block was assigned for the town's parish church. The town was surrounded by defensive walls with rows of towers and three main gates, including the Kulm Gate from the north-west and the Castle Gate along the same axis from the north-east. The Bridge Gate was placed on the northern side. The main circulation arterial consisted of two parallel streets that ran along the axis of the plan. These were the southern arterial, named after its gates_Chełmińska and Zamkowa - and the northern arterial, whose westward section was named Kościelna Street, and its eastward section Kupiecka Street. The most important perpendicular street was Mostowa, which led to the northernmost gate. A town hall and butchers' and bakers' benches were sited on the market square. Two suburbs emerged as early as in the Middle Ages: a wharf with granary buildings from the south, and an outer ward from the east, between the castle and the town. ${ }^{8}$

In terms of composition, the layout can be inscribed onto a grid of modules with a side ratio of 5:7, where the base unit is a square with sides the length of 11 rods (calculated based on a foot that is equivalent in length to $0.3 \mathrm{~m}$ ) or a 5:8 module grid, when the base unit is assumed to be a square the length of 1 sznur (calculated based on a foot that is equivalent in length to $0.288 \mathrm{~m}$ ) - however, in this case, the north-western corner would be outside of the grid.'

The parish church was built in a multi-stage process which started in the second half of the fourteenth century and lasted to the middle of the seventeenth century. Ultimately, the church was given the form of a basilica with a tower from the west. ${ }^{10}$

A castle of the Teutonic Order was built along the extension of the town's main axes, on the north-eastern side. It was erected on a square-shaped plan, following a regular type with corner towers. The main tower, to the north-east, features pronounced machicolations. ${ }^{11}$ Together with the church from the west, it was one of the two main landmarks of Świecie's skyline until as late as the nineteenth century. The market square also featured a town hall, which probably operated up to the third quarter of the nineteenth century. Unfortunately, there is no information about its form or appearance. ${ }^{12}$

During the Middle Ages, the town was a local market for crafts, yet it did not achieve considerable regional significance. In the first half of the fifteenth century it was inhabited by around 500-600 people. As per the provisions of the second peace treaty of Torun in 1466, Swiecie found itself within the borders of the Kingdom of Poland. Craftsmanship and agriculture continued to play a major role during this period, as did trade, but to a much lesser extent. $^{13}$

\footnotetext{
${ }^{8}$ ARSZYŃSKI, Marian. Szৃtuka regionu świeckiego. In: JASIŃSKI, Kazimierz (ed.). Džieje Świecia nad Wisła i jego regionu, vol. 2. Warsaw-Poznań-Toruń: Państwowe Wydawnictwo Naukowe, Towarzystwo Naukowe w Toruniu, 1980, pp. 249-252. See also: KALINOWSKI, Wojciech, Rozwój miast w Polsce. In: ZIN, Wiktor (ed. ). Zabytki urbanistyki i architektury w Polsce. Odbudowa i konserwacja, vol. 1. Warsaw: Arkady, 1986, p. 24.

${ }^{9}$ The geometric and metrological analysis was performed by SZCZERBIŃSKI, Sławomir. See: SZCZERBIŃSKI, Sławomir, Urbanistyka miasta sprz̨żonego z zamkiem w Państwie Kryyżackim w Prusach na praykktadzie Świecia $i$ Reszla, Master's thesis written under the supervision of Dr. Marian ARSZYNSSKI, Institute of Monument Studies and Conservation of the NCU in Torun, 1982, manuscript stored in the archives of the Department of Art Conservation of the NCU, sign. 124, pp. 102-107.

${ }^{10}$ ARSZYŃSKI, Sztuka..., p. 260.

${ }^{11}$ More about the castle can be found in: SPŁAWSKA-KORCZAK, Maria, Zamek kràyżacki w Świeciu. Próba rekonstrukcii zamku nysokiego w średnionieczu, Toruń: Wydawnictwo Naukowe Uniwersytetu Mikołaja Kopernika, 2014.

${ }^{12}$ ARSZYŃSKI, Sztuka..., p. 252.

${ }^{13}$ Atlas..., p. 8
} 
During the Modern period, a timber church of St. Michael stood in the city's northern section, on the elevation. It was taken over by monks from the Order of St. Bernard in 1640. Around the end of the seventeenth and the beginning of the eighteenth century, the Order built a new masonry temple along with a monastic complex. The suburbs included a baths building and a malt house. The castle grounds also included a mill and a brewery that was built in the first half of the seventeenth century. ${ }^{14}$

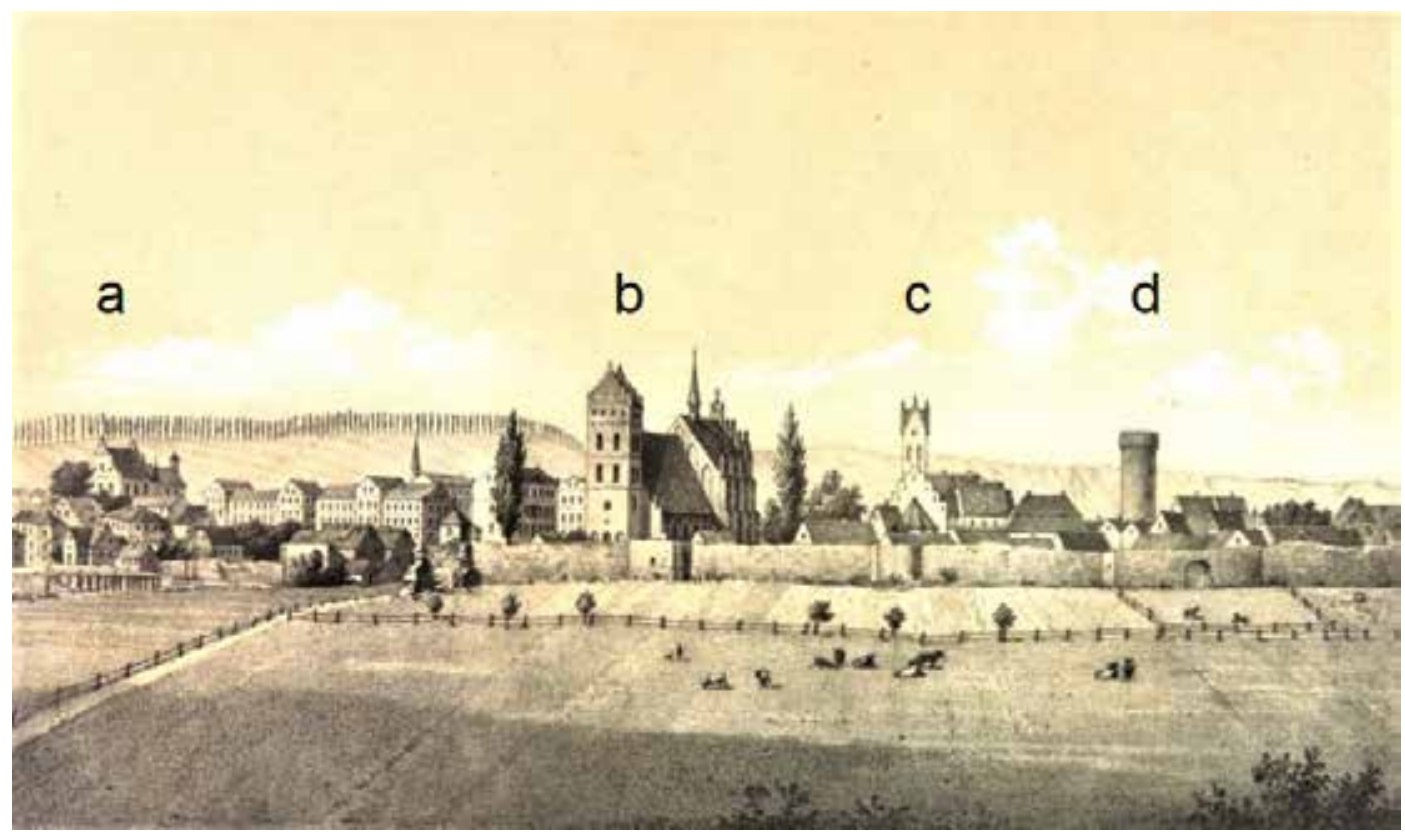

Fig. 5. Siwiecie, panroama from the west. Legend: a - church and monastery of the Order of St. Bernard; b parish church, c - Evangelical church d - Teutonic castle (source: R. Wegner, op. cit.)

In the Middle Ages and during the early modern period, the town was sacked multiple times by attacking armies. It was even burned to the ground during the Swedish invasion. The Northern War did not spare it either. However, it suffered its most severe damage from flooding, which has been a regular occurrence since the fifteenth century. ${ }^{15}$

Towards the end of the eighteenth century, the town's population was just over 1000. After the first partition of Poland, it was incorporated into the Kingdom of Prussia, becoming the seat of a Landkreis in 1815. One of the few new construction initiatives at the time was the erection of an Evangelical church in 1795. It was sited at the north-western corner of the market square, which was done intentionally. In the middle of the nineteenth century, a tower was added to it from the side of the frontage, which allowed it to compete with the parish church as a landmark (Fig. 5). ${ }^{16}$

In 1830, there were 139 houses and 117 smaller buildings in Świecie. Only 35 of these were masonry buildings. By then the town's burghers had already demanded that the town be relocated to the safe, higher ground on the northern side of the river, which was already being gradually settled. Ultimately, the decision to do so was made in 1857, after a series of disastrous

\footnotetext{
${ }^{14}$ Ibidem, pp. 8-9.

${ }^{15}$ Ibidem, p. 8.

${ }^{16}$ BIRECKI, Piotr. Ewangelickie budownictwo kościelne w Prusach Zachodnich. Toruń: Wydawnictwo Naukowe Uniwersytetu Mikołaja Kopernika, 2014, p. 105.
} 
K. Zimna-Kawecka - D. Kuśnierz-Krupa - M. Krupa: Heritage of (non-)existing cities...

floods, particularly those of 1854 and $1855 .{ }^{17}$ In the 1820s, a new Bydgoszcz-Gdańsk route was delineated through the area. Work began on relocating the town's administrative centre to the area of the former suburb - a post office, telegraph station, and courthouse were built there in the first half of the nineteenth century. The new layout was aligned with the previously mentioned road and a set of forking trails that led to the bridge across the Wda (Fig. 1). It also incorporated earlier development. Streets led perpendicularly outwards from a rectangular market square (called the Large Market Square). A second square, the so-called Little Market Square, was demarcated to the south-east from the main square. This layout abutted the earlier monastery and its garden. A monumental asylum complex was built on its grounds during the Prussian period. ${ }^{18}$ An Evangelical and a Catholic cemetery were demarcated to the west of the new urban layout. The land further west was assigned to a sugar mill and other industrial buildings. The new part of the town became the site of a court building (which was extended), school buildings, an Evangelical church, a synagogue, a power plant, and a county hospital. The improved living conditions offered by Świecie's new site led to an increase in its population, which reached 8,000 in 1910. By the 1880s, the area of the Old Town had only 200 inhabitants, and the seat of the town's administration was relocated from the old town hall to a building near the Large Market Square in 1879. ${ }^{19}$ The demolition of the former town hall and other buildings began, sparing the parish church, the parsonage, and the Evangelical church. The walls of the dismantled buildings were being used as a source of building material for the houses in the new section. The authorities prohibited erecting new buildings and renovating existing ones in the old town area. The residents were given financial aid to support them in moving to new places of residence, under the condition that they demolish their old dwellings. ${ }^{20}$

In 1920, the town once again found itself inside the borders of the Polish Republic, becoming a part of the Pomeranian Voivodeship. It retained the status of a medium-sized city, which developed northwards and westwards (for instance in the form of the Chmielniki villa district). The 1945 wartime operations of the Second World War inflicted significant damage to the town's medieval section-particularly the parish church, which was located on the front line. In the 1960s, the construction of the Paper and Cellulose Plant (to the west of the new town) led to another dynamisation of Świecie's spatial development and the increase of its population (at present the city has 25.7 thousand inhabitants). ${ }^{21}$ Workers' housing block complexes were built, along with single-family developments. Individual houses were also built on plots along the main streets of the old town and Zamkowa Street, which leads eastward to the castle ruins. The areas located to the south of the old layout, which extends to the flood embankments of the Vistula River, became the site of allotment gardens. Similar gardens were planned in areas extending to the east of the castle.

\footnotetext{
${ }^{17}$ KÖTZ, Gustav. Die Verlegung der Stadt Schwetz aus der Weichselniederung auf die Höhen am linken Schwarzwasserufer (1830-1885). Schwetz: Büchners Buch - und Steindruckerei, 1905. See also: BORZYSZKOWSKI, Józef, MIOTKA Marian (elab.). Przeniesienie miasta Świecia z doliny Wisły na wzgórze na lewym brzegu Czarnej Wody. In: BORZYSZKOWSKI, Józef (ed.). Świecie. Ksiega jubileuszu 800-lecia. Świecie-Gdańsk: Urząd Miejski w Świeciu, Instytut Kaszubski, 1998, pp. 158-181.

18 The "Prussian period" in the history of the Polish lands covers the years 1772-1918, which were spent under Prussian rule, as a result of the partitions of Poland (Polish-Lithuanian Commonwealth) by the Russian Empire, the Kingdom of Prussia and the Habsburg Monarchy.

${ }^{19}$ Atlas..., pp. 7-8.

${ }^{20}$ KÖTZ, Die Verlegung..., p. 29, 42, 55, [from:] SZCZERBIŃSKI, Urbanistyka miasta..., p. 146.

${ }^{21}$ Atlas..., p. 8.
} 


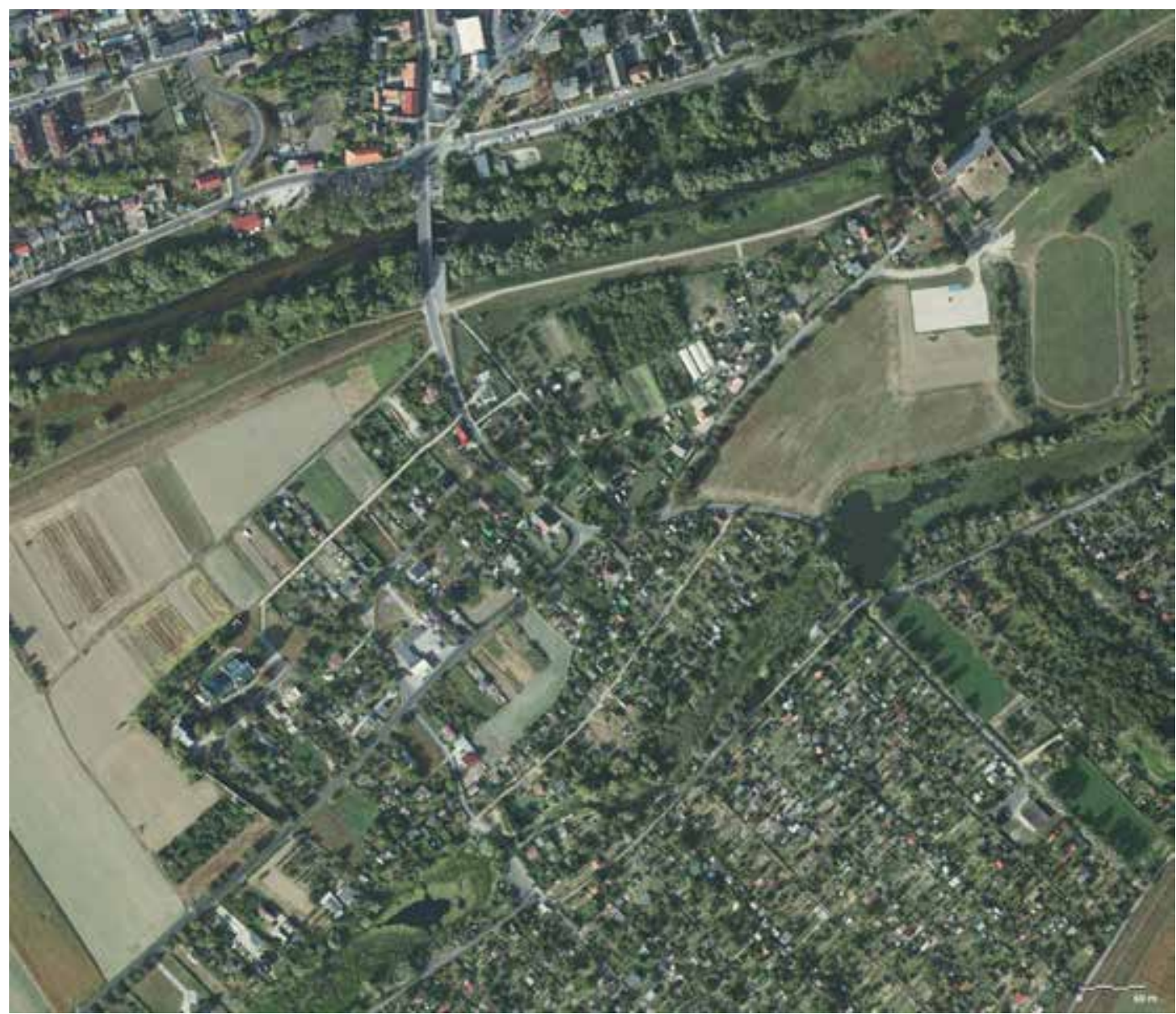

Fig. 6. Świecie (Kuyavian-Pomeranian Voivodeship). Satellite image of the medieval town and castle ruins (source: https://mapy.geoportal.gov.pl/imap/Imgp_2.html?gpmap=gp1 , 21.02.2020).

4. Extant state and the applicable policy concerning spatial development and the preservation of Świecie's old medieval town layout

The now historical urban area, the castle ward, and the adjacent areas have a park, and a recreational and agricultural character, with loosely spaced single-storey housing and agricultural buildings (Fig. 6, 7). It is connected with the new part of Świecie in the same way as it was in the past-by a bridge across the Wda River and Mostowa Street. The layout of the medieval plan, undistorted by nineteenth-century development, has survived in its essential circulatory divisions, as demarcated by three asphalt streets that form the rectangular outline of the former plan: in the north and west by Farna Street, in the south by Polskiego Czerwonego Krzyża Street (hereafter referred to as PCK Street), and Mostowa Street from the east. The remaining circulation routes survived either fully or partially in the form of dirt roads. An irregular square with a petrol station is currently located at the site of the former market square (Fig. 8). There is no preserved historical development and there are no plot divisions in the areas previously occupied by internal urban blocks. Land division, in the form of rectangular, elongated plots oriented with their shorter sides flush to the streets are a reference to (and are partially derived 
K. Zimna-Kawecka - D. Kuśnierz-Krupa - M. Krupa: Heritage of (non-)existing cities...

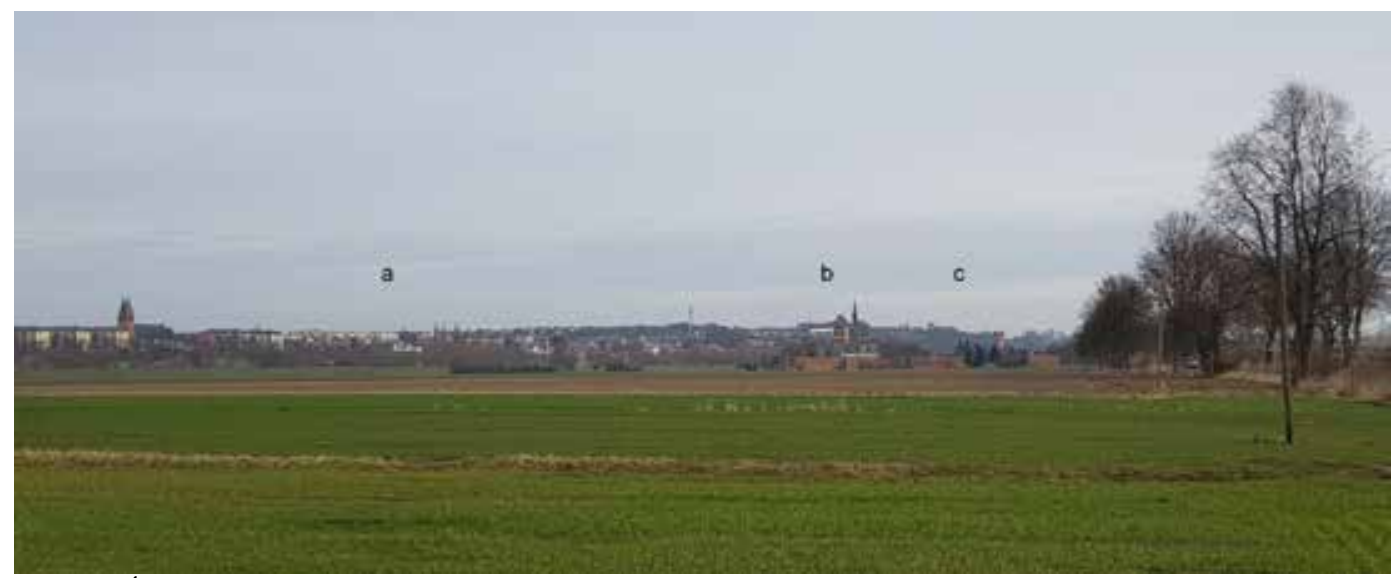

Fig. 7. Swiecie, view of the town's panorama from the southwest. Legend: a - contemporary town, b - Old Town, parish church, c - Teutonic castle tower (phot. by M. Prarat, 2020).

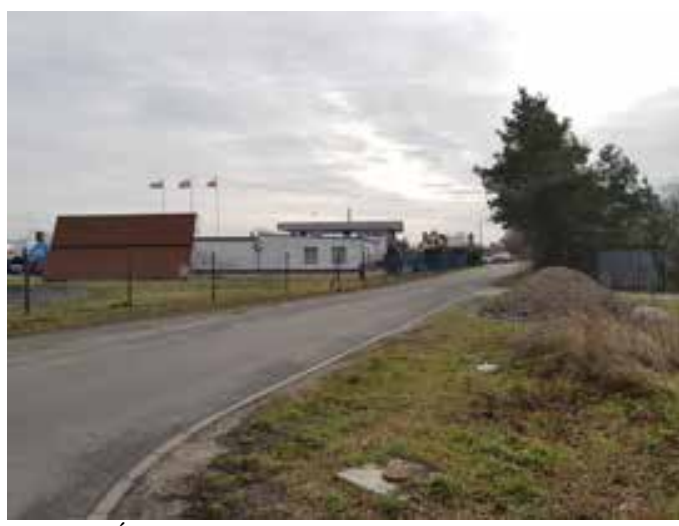

Fig. 8. Swiecie, view of the former market square with a gas station as seen from Farna Street (phot. by M. Prarat, 2020).

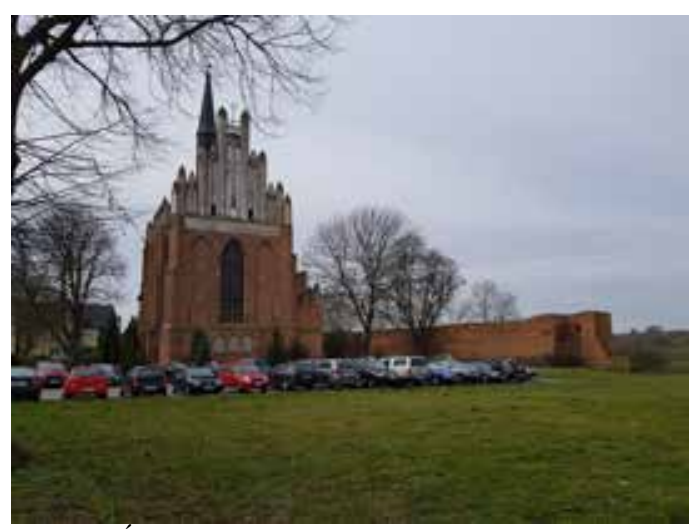

Fig. 9. Swiecie, view of the parish church and its yard from Farna Street. Westward view (phot. by M. Prarat, 2020).

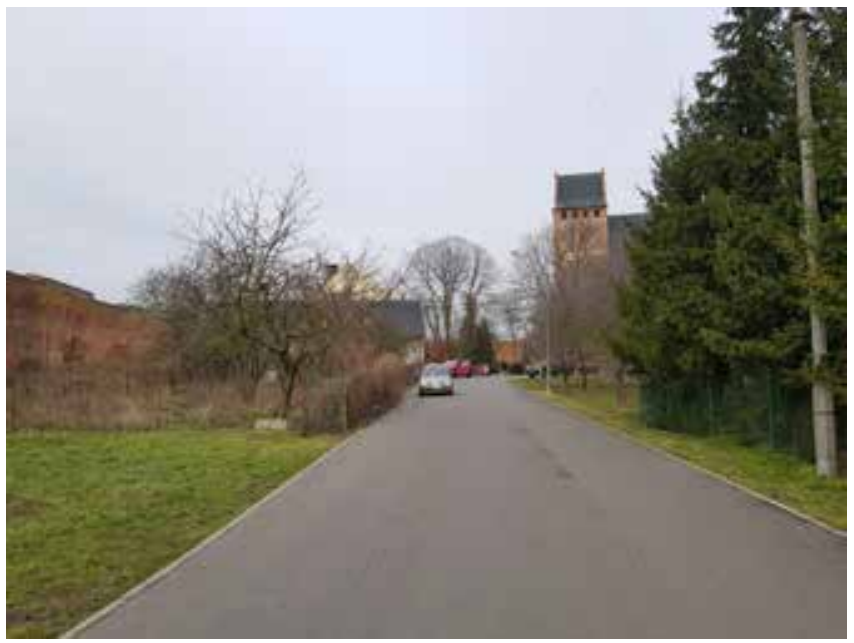

Fig. 10. Swiecie, view of the church from Farna Street, from its section along the surviving town walls

(phot. by M. Prarat, 2020).

from) the historical divisions visible on an 1886 cadastral plan (Fig.1, 4). ${ }^{22}$

Of the town's historical architecture, only the parish church of St. Nicholas survived. Partially rebuilt (Fig. 9), it stands on a square outlined by a masonry fence and the relics of the town walls along their northern section between the end

${ }^{22}$ Cf. cadastral map, available at: Geoportal 2, https://mapy.geoportal.gov.pl/imap/Imgp_2.html?gpmap=gp1, and the 1886 cadastral map from Atlas..., Fig. 1. 
of the churchyard and, from the west, up to PCK Street (Fig. 10). From the south, the castle ruins can be reached via Zamkowa Street, which has an asphalt surface, while from the north they are approached by a paved alley promenade along the Wda. The northern wing of the castle and some of its curtain walls along other sections have survived. From the south, the castle is abutted by sports and recreation grounds with a sports pitch.

The entire formerly urbanised area is irregularly overgrown with various types of greenery: low-growing plants, bushes, and trees that obscure houses, farm buildings, and allotment gardens from the side of the streets. Some of the plots are undeveloped. There are fields and meadows around the former town and the castle grounds, behind the line of allotment complexes. The panorama of the former town still features the two medieval brick landmarks: the massing of the temple and the castle ruins with their thirty-four-metre-tall tower topped with machicolations and crenels (Fig. 7).

The church, the town walls, and the remains of six towers and a fragment of the Kulm Gate, along with the ruins of the castle and their immediate vicinity, are registered heritage sites. The spatial development conditions and directions study of 2012 extends the protective zone: full, area-based conservation and archaeological protection around the castle, the former block of the western town along with the churchyard and the surviving defensive wall sections, and another conservation zone which protects the vicinity of heritage sites in terms of maintaining its essential elements, along with archaeological protection. ${ }^{23}$ The area covered with allotment gardens to the south and east of the layout was designated as an exposition zone. ${ }^{24}$

The area of the church, the former market square, and the castle were assigned for adaptive reuse as residential and service areas meant to reinforce commercial service potential; the remaining areas of allotment gardens were assigned for individual recreation with a prohibition on development; while the area to the south of the castle was allocated for urban greenery (landscaped and non-landscaped) with recreational and ecological functions, with a prohibition on transformation and changes in use. A ban on erecting new residential developments and industrial, storage, and service buildings has been imposed on the entire area, with the exception of functions associated with tourism, recreation, and sports, in addition to the area with applicable land development plans (the strip along the Wda) and their detailed provisions. One of the postulates indicates the protection of the exposition of the Old Town's relics. ${ }^{25}$ The area to the south and east of the castle, along with its ruins, was also placed under Natura 2000 habitat protection. ${ }^{26}$

The area's greenery requires landscaping as it has become overgrown and obscures historical visual axes. From a panoramic perspective, the entire complex presents landscape value, yet without the values of an urban landscape. In the 1970s, selective archaeological digs and studies were performed in the area of the medieval town within the perimeter of its walls (the western

\footnotetext{
${ }^{23}$ Rejestr zabytków woj. kujawsko-pomorskiego (Heritage site registry of the Kuyavian-Pomeranian Voivodeship), accessed 31 December 2019, pp. 81-82, https://www.nid.pl/pl/Informacje_ogolne/Zabytki_w_Polsce/rejestr-zabytkow/zestawienia-zabytkow-nieruchomych/; Studium uwarunkowań i kierunków zagospodarowania przestrzennego gminy Świecie 2012 (Spatial development conditions and directions study for the municipality of Świecie), Appendix 4 [city plan]: Kierunki zagospodarowania-plan, Appendix 5 [city plan]: Kierunki zagospodarowania przestrzennego - plan, accessed 15 May 2019, http:/ / bip.swiecie.eu/?app=uchwaly\&nid=8734\&y=2012.

${ }^{24}$ Appendix 4 of Studium...

${ }^{25}$ Appendix 5 of Studium...; Studium..., part 2 (text): Appendix 2: Kierunki zagospodarowania, p. 14, 20.

26 "Specjalny Obszar Ochrony Zamek Świecie" (Świecie Castle special protection zone) encompassing a winter habitat for bats, see: Studium..., part 1 (text): Uwarunkowania zagospodarowania przestrzennego, p. 70; Appendix 5 of Studium...
} 
K. Zimna-Kawecka - D. Kuśnierz-Krupa - M. Krupa: Heritage of (non-)existing cities...

wall near the gate and in the south-western corner, in the eastern corner near the end of Farna Street, and near the end of PCK Street), as well as at the site of the market square and the castle. However, only the sections from the north-western and western sides were exposed. No attempt was made to highlight and preserve the plan of the historical market square. Tourist traffic, which typically ignores the south-western direction with the church, is largely focused around the castle ruins and its observation tower. The ruin became the target of revitalisation and land development measures aimed at tourism, together with the divisive reconstruction of wings that have not survived in their original form. Their designs were not based on architectural research. ${ }^{27}$ The measures aimed at the castle and undertaken by the town's authorities were not linked with any research within the former urban centre, and efforts were not made to draft a shared conservation and development programme that could highlight the exceptional values of the entire former Teutonic complex and make them more legible.

\section{History and overview of Krasiczyn's early modern urban layout}

Krasiczyn was founded on a plain, on the right bank of the San River, as an early modern urban and residential complex. It was founded by the Krasicki family. Construction on the complex was initiated by the family's progenitor, Jakub of Siecin, who became the owner of extensive landed estates in the land of Przemyśl through his marriage to Barbara Orzechowska. ${ }^{28}$ At the time, the Krasicki family latifundium encompassed 14 villages. ${ }^{29}$ Jakub of Siecin took on the family name Krasicki, derived from the locality of Krasice, which was a part of the dowry of his wife, Barbara. ${ }^{30}$ The construction of the residential complex was continued by his son, Stanisław Krasicki, while his grandson, Marcin, remodelled it after a Mannerist fashion. The latter's contributions to Krasiczyn were particularly significant. ${ }^{31}$ His activity in the years $1598-$ 1631 allowed the complex to flourish the most. Marcin Krasicki held many government posts, and was devoted to the king and enjoyed his favour. He occupied the posts of, among others, the starost of Przemyśl, the voivod of Podole, the castellan of Lviv, and senator. ${ }^{32}$ He was also known as a patron of the arts and an outstanding man of his time, with multiple talents. He contributed to the extension of the Krasicki family estate, which in the 1630s encompassed sixty villages and three towns: Krasiczyn, Krzywcza, and Dubiecko. ${ }^{33}$

As we go back to Krasiczyn - the greatest of the three towns founded by the Krasicki family - it should be noted that its plan was influenced by Renaissance theory and practices. Krasiczyn's urban layout is an example of a town-and-residence complex with compositional linkages. This linkage takes on the form of a compositional axis demarcated between the residence and the town. This axis, which is also a circulation artery, links the city's central

\footnotetext{
${ }^{27}$ This gap has been partially filled by the latest architectural studies. See: GRZELIŃSKA, Nina, Piwnice zamku krzyżackiego w Świeciu—technika budowy i przekształcenia w świetle badań architektonicznych oraz problematyka konserwatorska, Master's thesis written at the Heritage Protection course, specialisation in conservation, under the supervision of Dr. PRARAT, Maciej, Toruń, 2019, manuscript stored in the archives of the Department of Art Conservation, NCU.

${ }^{28}$ HORWAT, Jerzy. Zarys genealogii rodu Krasickich do 1717 r. In: Przemyskie zapiski historycžne. Przemyśl: Oddział Przemyski Polskiego Towarzystwa Historycznego, 3: 1985, pp. 61-64.

${ }^{29}$ KSIAZŻEK, Mieczysław, Zagadnienia genesy rozplanowania i typologii miast prywatnych XVI $i$ XVII wieku w Potudniowej Małopolsce, CUT monograph no.70, Kraków: Politechnika Krakowska, 1988, p. 55.

${ }^{30}$ HORWAT, Zarys genealogii..., pp. 61-64.

${ }^{31}$ GUERQUIN, Bohdan. Zamki w Polsce, Warszawa: Arkady, 1974, pp. 167-170.

${ }^{32}$ HORWAT, Zarys genealogii..., p. 75.

${ }^{33}$ KSIAZŻEK, Zagadnienia genezy..., pp. 55-56.
} 


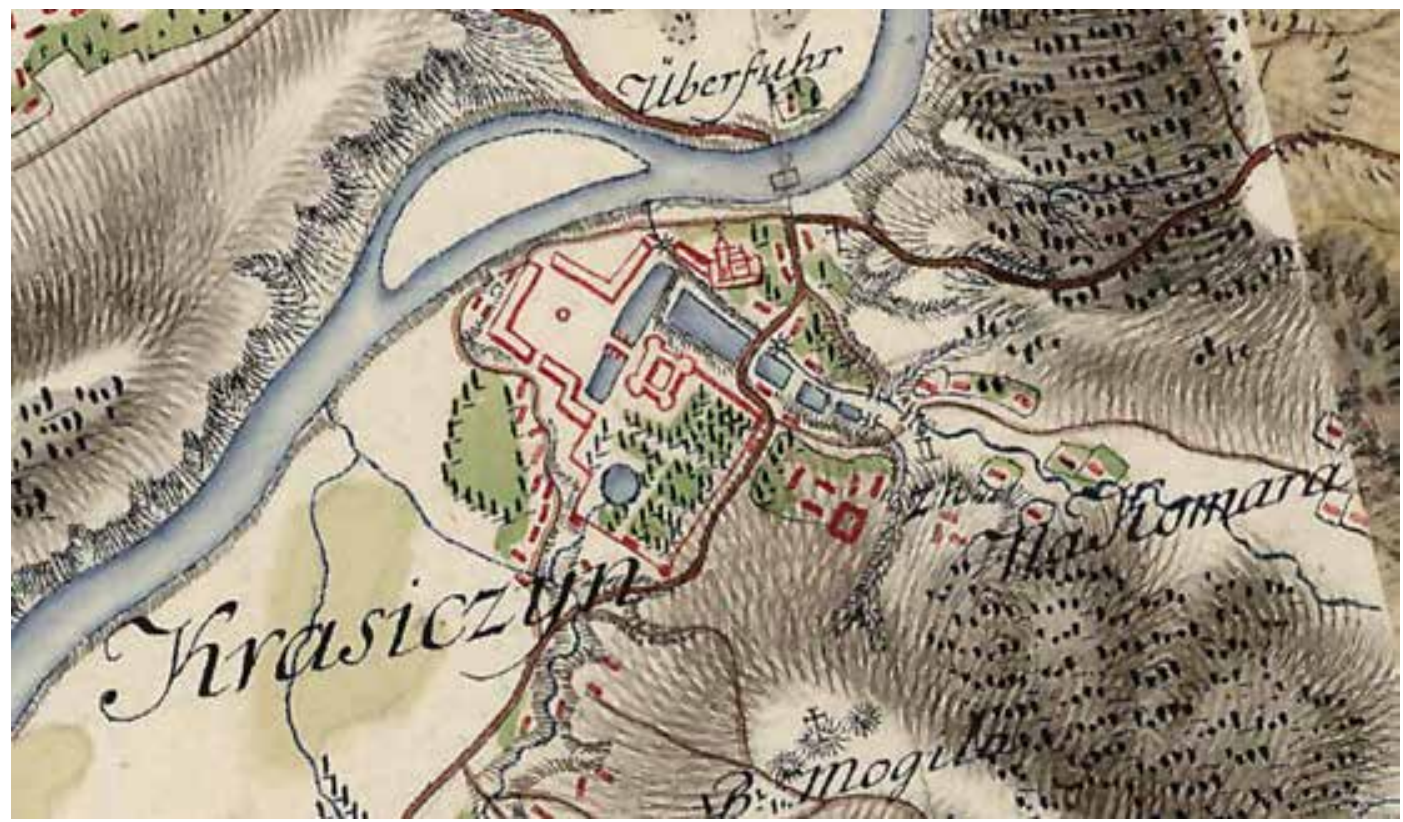

Fig. 11. Krasiczyn on the First Military Survey-Map of Galicia and Lodomeria 1779-1783, (source: www. mapire.eu, 20.02.2020)

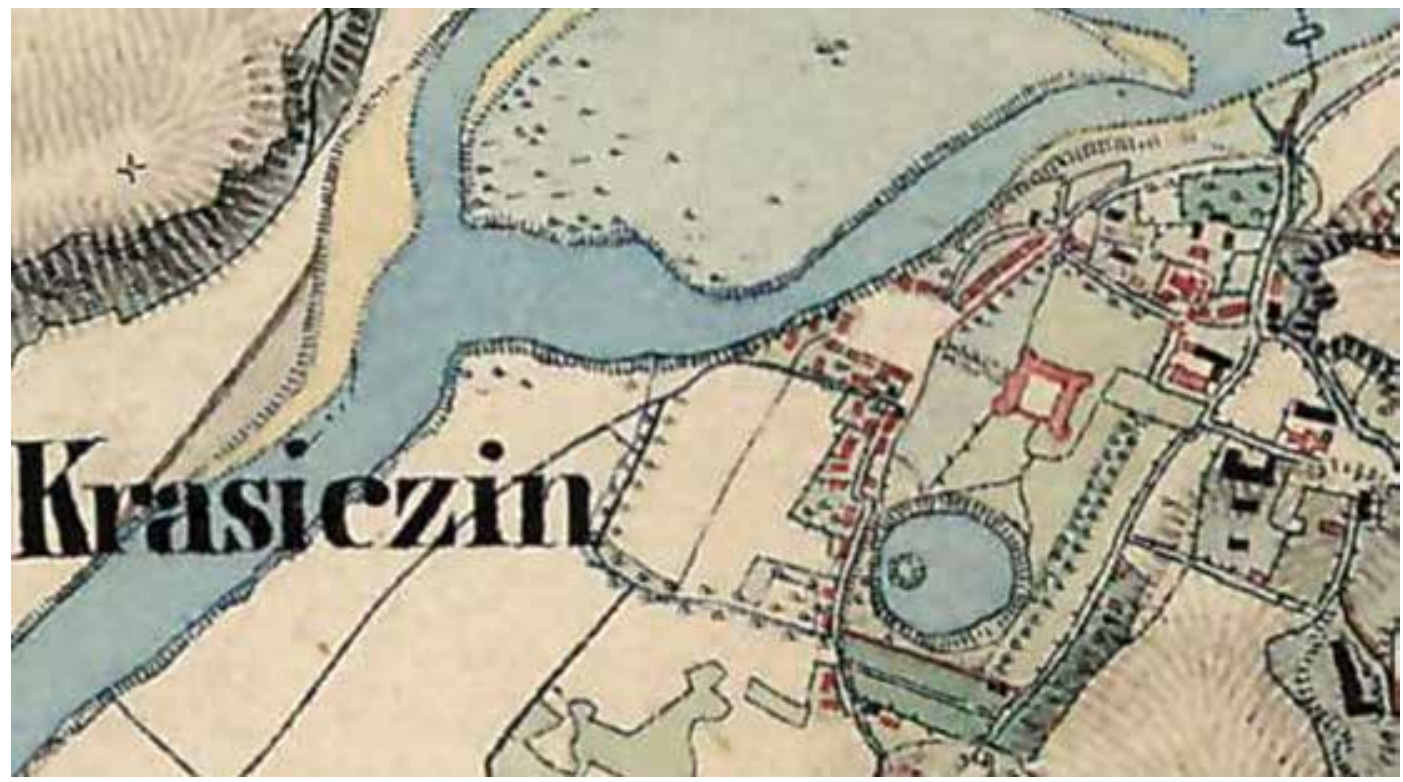

Fig. 12. Krasiczyn on the Second Military Survey —Map of Galicia and Bukovina from 1861-1864, (source: www.mapire.eu, 20.02.2020)

square, which opens up towards the residence, with the main entrance to the Krasicki family home. Of note is the fact that in Krasiczyn's urban layout one can point to only two of the three basic elements of Renaissance town-and-residence layouts: the town and the residence. The complex was not given a defensive perimeter in the form of fortifications, which is why, when the typology of Renaissance town-and-residence layouts is concerned, it should be labelled 
K. Zimna-Kawecka - D. Kuśnierz-Krupa - M. Krupa: Heritage of (non-)existing cities...

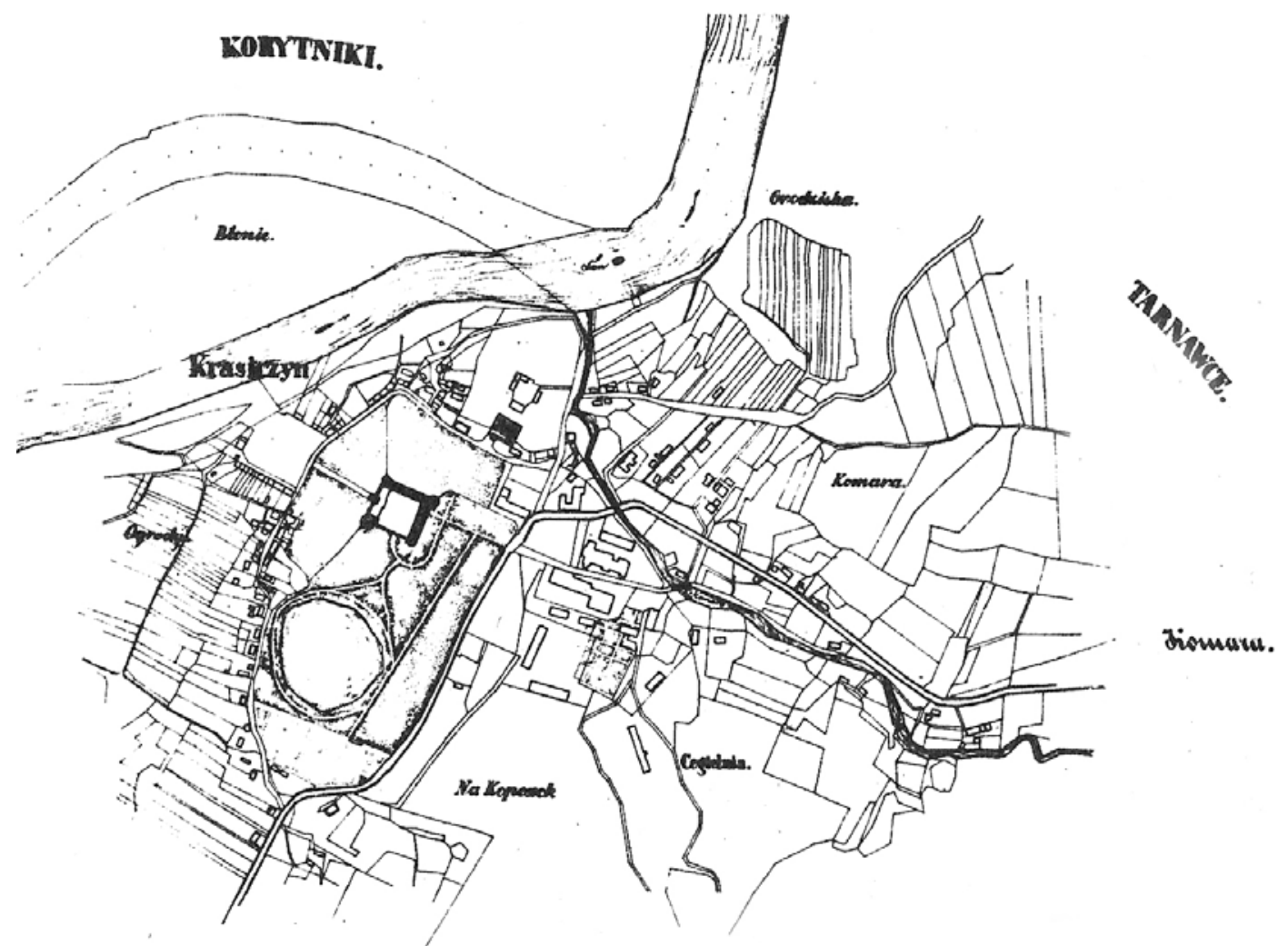

Fig. 13. Krasiczyn, plan cadastral plan from 1852 (copy from the collection of the archives of the Chair of the History of Architecture, Urban Planning and the Arts of the Faculty of Architecture of the Cracow University of Technology).

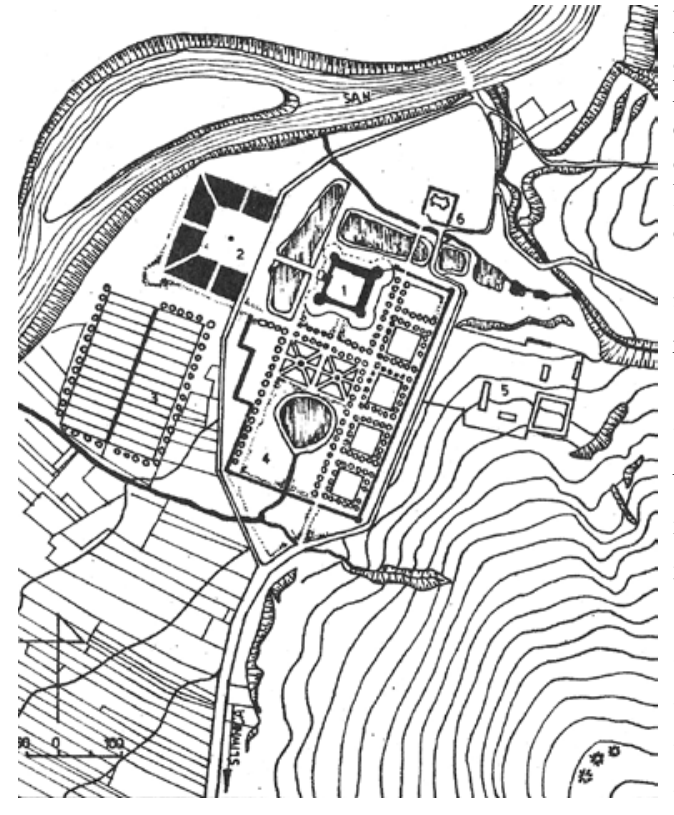

Fig. 14. Krasicayn, reconstruction of the early modern urban and residential complex by $M$. Ksiażek.

Legend: 1- residence, 2- urban layout, 3 - town gardens, 4 - Italian garden, 5- grange, 6- church. (collection of the Chair of the History of Architecture, Urban Planning and the Arts of the Faculty of Architecture of the Cracow University of Technology).

as a layout with compositional linkages, albeit an incomplete one. ${ }^{34}$ (Fig. 11, 12, 13, 14)

Although this paper focuses primarily on the town as one of the complex's two elements, it would be inappropriate not to briefly discuss the residence, which is considered to be one of the most beautiful magnate mansions in Poland (Fig. 15, 16). The Krasicki residence takes the form of a castle laid out on a quadrangular plan, with moats and four cylindrical artillery towers (modelled after the German Bastei) at its corners: the Divine, the Papal, the Royal, and the Noble tower, respec-

$\overline{{ }^{34} \text { Ibidem, pp. 159-160. }}$ 


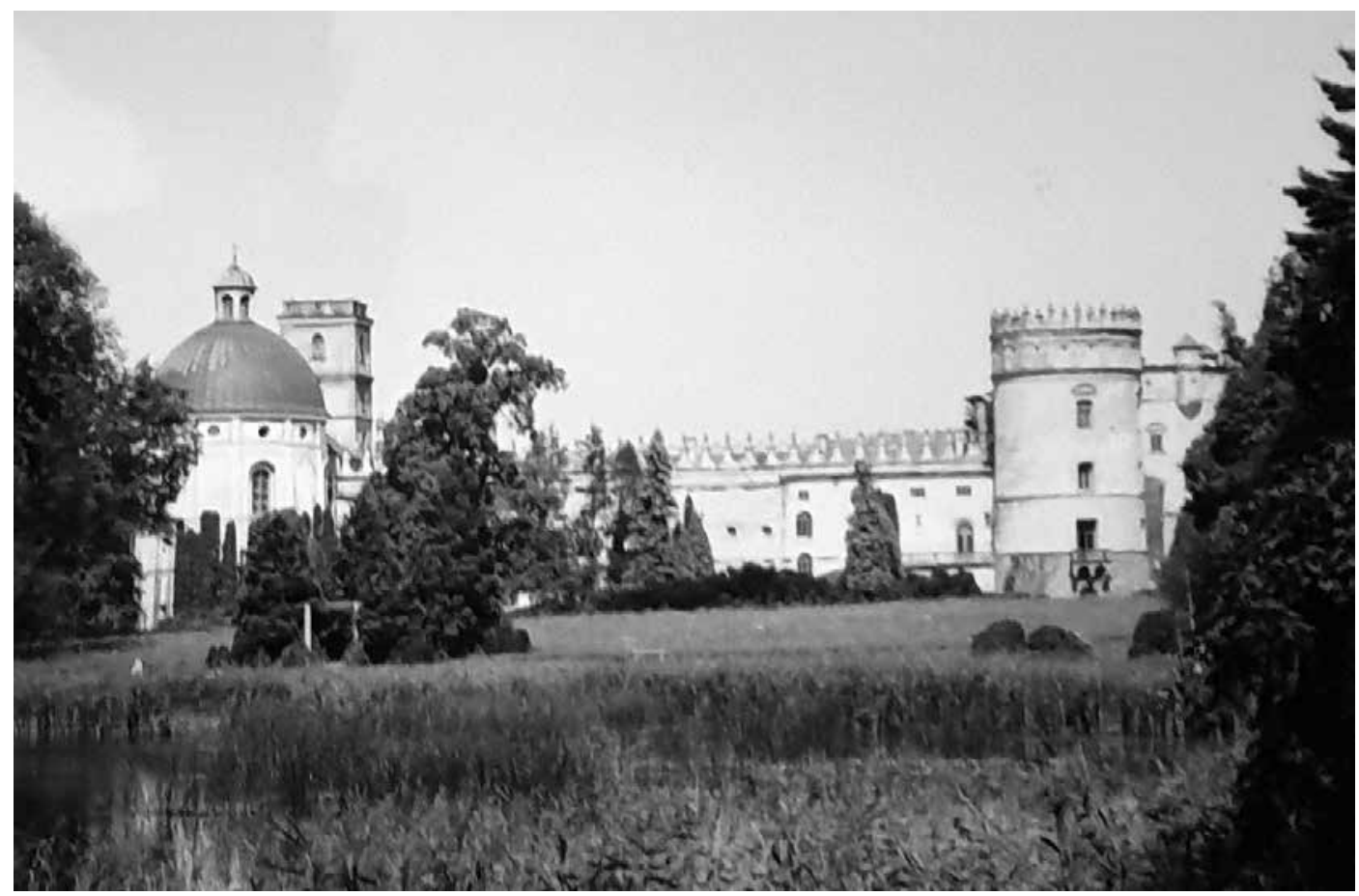

Fig. 15. Krasicayn, view of the residence, as seen in the 1960s (photograph from the collection of the Chair of the History of Architecture, Urban Planning and the Arts of the Faculty of Architecture of the Cracow University of Technology).

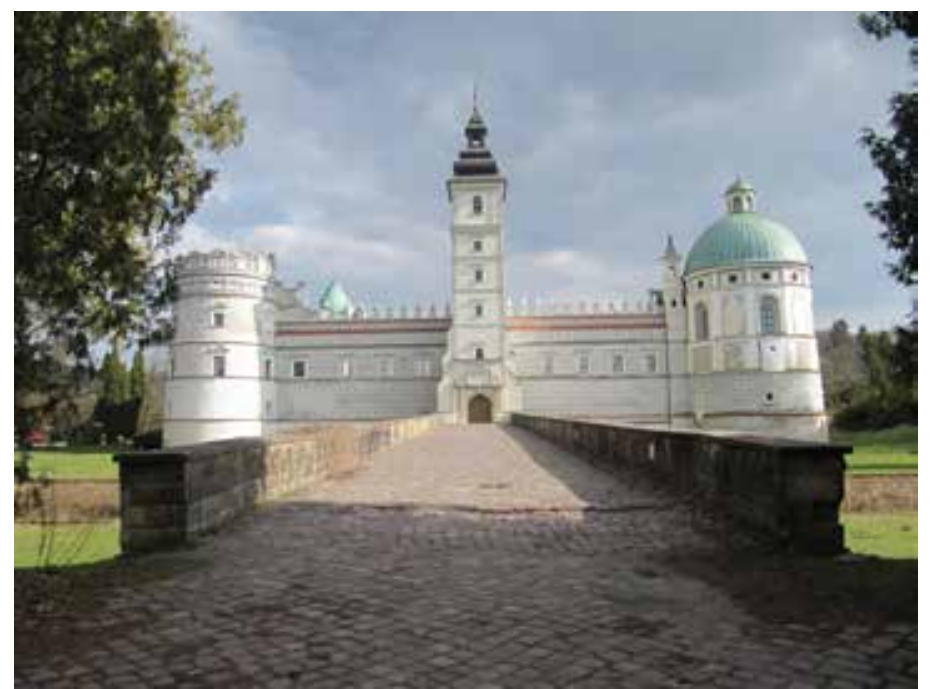

Fig. 16. Krasicayn, view of the residence from the west, as seen in the present (photograph from the collection of the Chair of the History of Architecture, Urban Planning and the Arts of the Faculty of Architecture of the Cracow University of Technology, N. Stojak 03.2020). 1580, while the third involved the extension of the structure in the spirit of Mannerism by Marcin Krasicki. Subsequent remodelling projects carried out throughout the eighteenth cen-

${ }^{35}$ GUERQUIN, Zamki..., p. 169. 
tury and at the start of the nineteenth century primarily focused on the residential structures or general maintenance, e.g. reconstruction after a fire, which took place in $1852 .{ }^{36}$

The residence, as an outstanding work of Polish early modern period civil engineering, has been attracting the attention of architectural and urban planning history scholars for years. The town fared differently, as it never developed into a more significant centre. The reasons for this state of affairs include its location near the San river, on a flood plain, which was the cause of its ultimate downfall. Despite this, it should be noted that it was one of the main elements of the previously mentioned town-and-residence layout, with indisputable Renaissance-era cultural values (Fig. 17, 18).

The town of Krasiczyn was founded in 1620 by Marcin Krasicki. ${ }^{37}$ The notion of expanding his family latifundium and extending the residence had probably carried over to the idea of building a seat for his family-the intended role of the urban centre demarcated to the west of the castle.

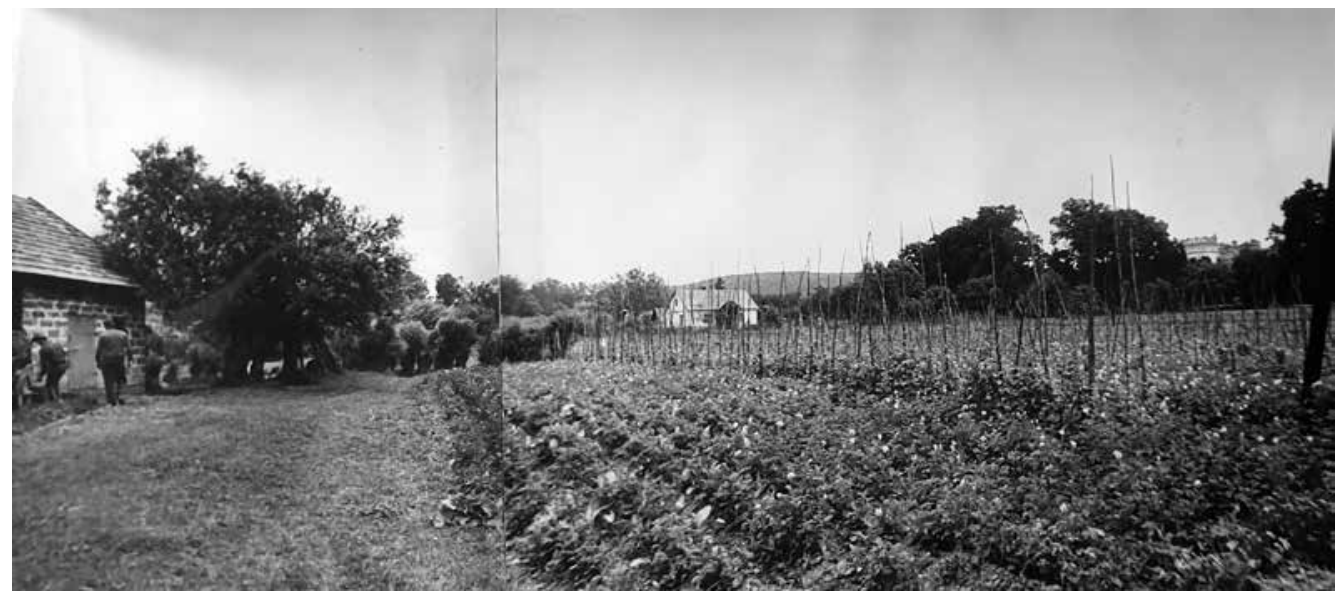

Fig. 17. Krasiczyn, view of the site of the former market square from the south, as seen in the 1960s. (photograph from the collection of the Chair of the History of Architecture, Urban Planning and the Arts of the Faculty of Architecture of the Cracow University of Technology, K. Kuśnierz).

Here it should be noted that the residence was initially oriented along the north-south axis. It was only during the Mannerist remodelling of the residence and-most probably_the need to form the town-and-residence layout, that the main axis of the complex was reoriented to the east-west direction. This was highlighted by the clock tower with a gate, which was crossed by the compositional axis leading to the town, with one of its frontages open towards the residence. This led to the formation of an urban layout distinctive to the Renaissance, with characteristics of compositional linkages (Fig. 11).

The town of Krasiczyn itself constituted a rather small centre, and its location determined its relatively poor spatial development opportunities. A square-shaped market square, measuring

\footnotetext{
${ }^{36}$ FRAZIK, Tomasz, Józef. Terenowe badania architektoniczne zamku w Krasiczynie w roku 1966. In: Materiały $i$ Sprawozdania Rz̧eszowskiego Ośrodka Archeologicznego za rok 1966. Rzeszów: Muzeum Okręgowe w Rzeszowie, 1968, pp. 223-230; FRAZIK, Tomasz, Józef. Z badań nad najstarszymi dziejami zamku w Krasiczynie. In: Biuletyn Historii Sztuki. 2(31), 1969, pp. 249-254; FRAZIK, Tomasz, Józef. Zamek w Krasiçynie. Series: Zesayt Naukowy. Architektura, Kraków: WPK, 12, 1968, p. 252; GUERQUIN, Zamki..., p. 169.

${ }^{37}$ KUŚNIERZ, Kazimierz. Miejskie ośrodki gospodarcze wielkich latyfundiów południowej Polski w XVI oraz XVII wieku. CUT monograph no. 83. Kraków: Politechnika Krakowska, 1989, p. 41.
} 


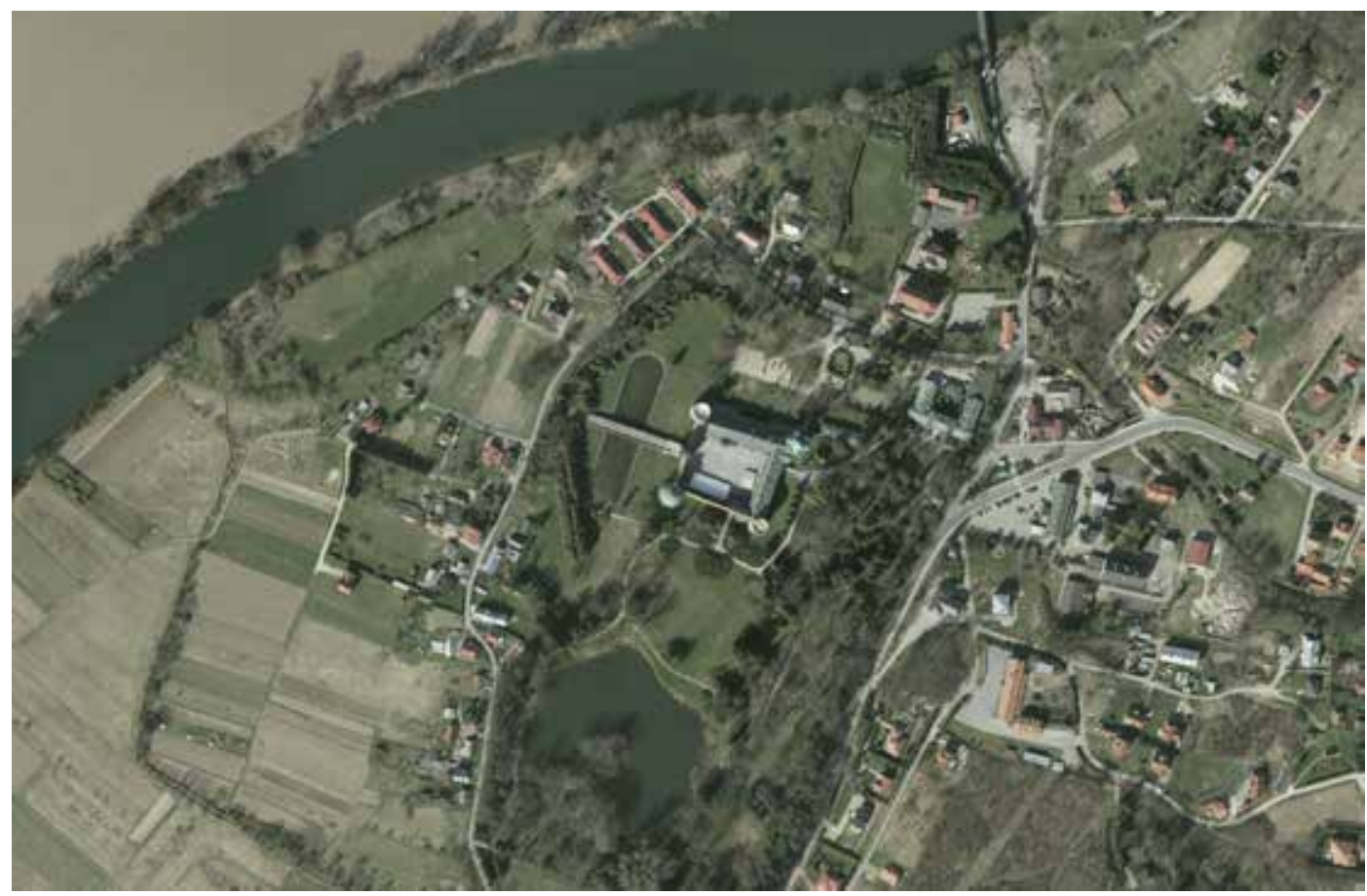

Fig. 18. Krasicayn (Subcarpathian Voivodeship). Satellite image of the historic urban layout of the residence and the town (source: https://mapy.geoportal.gov.pl/imap/Imgp_2.html?gpmap=gp0, 06.03.2020).

95 x $95 \mathrm{~m}$, was demarcated at its centre. It was surrounded by a single strip of urban blocks with a depth of around $36 \mathrm{~m}$. Based on this, following M. Książek, we can assume that the programme of this complex was minimal and the number of its settlers low. ${ }^{38}$ A total of six streets exited the market square. Four were delineated at the centre of frontages, which was a measure typical of the Renaissance. They included the street that formed the compositional and circulatory linkage with the castle. The north-western and south-western corners of the market square were the starting points of two additional streets (Fig. 14). This measure can be attributed to Renaissance models, namely to the circulation systems of ideal cities. Urban blocks, divided into settlement lots, initially featured timber buildings with forward-facing gables. Fully or partially brick buildings began to appear around the market square over time. Depending on size, the houses near the market were composed of between one to four rooms, alcoves, and chambers. They were typically also abutted by stable spaces. ${ }^{39}$

It is assumed that Krasiczyn was designed by Galeazzo Appiani, an Italian architect who lived and worked in Przemyśl.

The residents of Krasiczyn, mostly Poles, worked primarily to satisfy the needs of the castle and the latifundium. They were mostly craftsmen and farmers, while trade played a secondary role, as proven by there being no information about any markets or fairs. The centre, apart

\footnotetext{
${ }^{38}$ KSIAZŻEK, Zagadnienia genezy..., p. 116.

${ }^{39}$ MOTYLEWICZ, Jerzy. Miasta Ziemi Przemyskiej i Sanockiej w drugiej połowie XVII i XV III wieku. Przemyśl-Rzeszów: Południowo-Wschodni Instytut Nauk. w Przemyślu, Wyższa Szkoła Pedagogiczna w Rzeszowie, 1993, p. 215.
} 
K. Zimna-Kawecka - D. Kuśnierz-Krupa - M. Krupa: Heritage of (non-)existing cities...

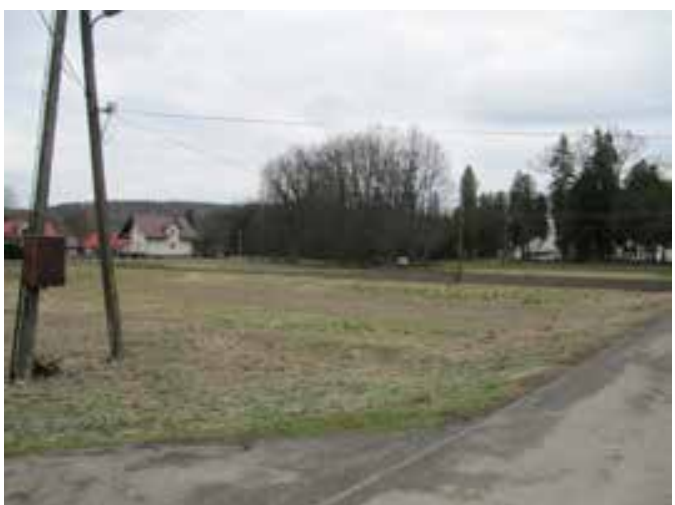

Fig. 19. Krasicayn, view of the site of the old market square from the southeast, as seen in the present. (photograph from the collection of the Chair of the History of Architecture, Urban Planning and the Arts of the Faculty of Architecture of the Cracow University of Technology. N. Stojak 03.2020).

from housing craftsmen and petty traders, was also inhabited by castle officials. ${ }^{40}$

The town-and-residence layout discussed above was supplemented by urban gardens planted to the south of the town, an Italian garden with plant beds near the residence, a grange, and a church (Fig.14). The centre also included a town hall (probably located in a house near the market square), a hospital, and a brewery. ${ }^{41}$

Krasiczyn remained in the hands of the Krasicki family until 1689, and changed hands numerous times afterwards, ${ }^{42}$ as its owners were unable to appropriately manage the complex and develop it. The exception here was Ludwika Potocka nee Mniszech, the wife of crown hetman Józef Potocki, who lived in Krasiczyn for over thirty years and tried to improve the economic condition of the then-significantly neglected latifundium. She renovated the castle, built a church and supported the town's inhabitants by granting them additional privileges. ${ }^{43}$

Ultimately, the town and the residence deteriorated, which caused Krasiczyn to lose its town rights, first in 1896 and then ultimately in 1934. ${ }^{44}$ Krasiczyn is currently a village in Przemyśl county and is the seat of a rural municipality.

\section{Extant state and the applicable policy of Krasiczyn's spatial development and protection}

As mentioned previously, the town of Krasiczyn, as an element of an urban layout with the characteristics of compositional linkages, does not currently exist (Fig. 18, 19). However, its traces are still visible in the field. The area of the former market square is currently an undeveloped space overgrown with grass (Fig.18, 20). The space is neglected and has no defined form of use, not even a recreational one, which enables field studies, including archaeological research. The historical landmark of this area-the residence-still acts as the highlight of

\footnotetext{
${ }^{40}$ GOSZTYLA, Marek, LICHOŁAI, Rafał. Nieistniejąca zabudowa przyrynkowa w Krasiczynie. In: Journal of Civil Engineering, Environment and Architecture, 64(34), 2017, pp. 151-158; FRAZIK, Tomasz, Józef. Z zagadnień rozwoju przestrzennego miasta Krasiczyna. In: Teka Komisji Urbanistyki i Architektury. Kraków: Oddział PAN w Krakowie, v. 11, 1977, pp. 33-42; MOTYLEWICZ, Miasta Ziemi..., pp. 98-150; MOTYLEWICZ, Jerzy. Krasiczyn w drugiej połowie XVIII w. Zarys wybranych problemów z dziejów miasta. In: Przemyskie Zapiski Historyczne..., pp. 99-111; WOLSKI, Krzysztof. Krasiczyn—rys dziejów zamku i latyfundium krasiczyńskiego. In: Rocznik Przemyski, 9(2), 1962, pp. 301-336.

${ }^{41}$ MOTYLEWICZ, Krasiczyn w drugiej połowie XVIII..., pp. 99-111.

${ }^{42}$ KAJZER, Leszek, KOLODZIEJSKI, Stanisław, SALM, Jan. Leksykon zamków w Polsce, Warszawa: Arkady, 2001, pp. 246-247; PROKSA, Michał, Studia nad zamkami i dworami ziemi przemyskiej od polowy XIV do poczatków XVIII wieku. Przemyśl: Archiwum Państwowe w Przemyślu, 2001, pp. 272-273.

${ }^{43}$ MOTYLEWICZ, Krasiczyn w drugiej połowie XVIII..., p. 103.

${ }^{44}$ SPÓRNA, Tomasz, DYMITROW, Mirek, KRZYSZTOFIK, Robert. Miasta zdegradowane i restytuowane w liczbach. In: DYMITROW, Mirek, KRZYSZTOFIK, Robert (eds.). Miasta zdegradowane i restytuowane w Polsce. Genez̧a, roźwój, problemy. Gothenburg: University of Gothenburg, 2015, p. 390.
} 


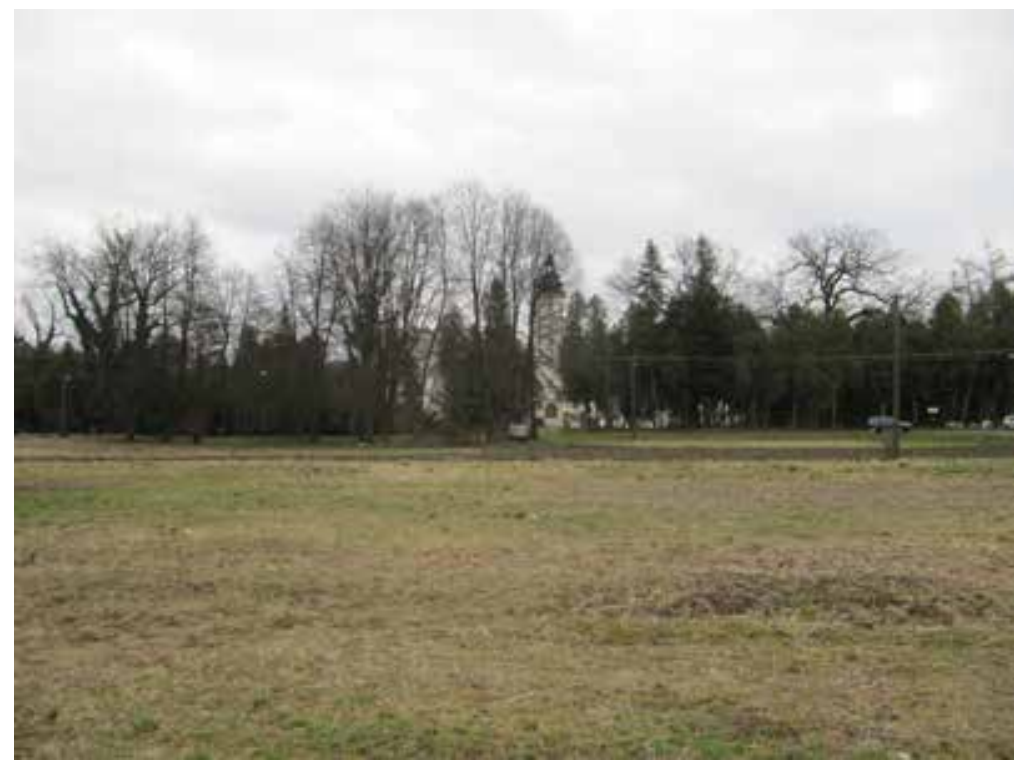

Fig. 20. Krasiczyn, view of the residence from the old site of the market square, as seen in the present. (photograph from the collection of the Chair of the History of Architecture, Urban Planning and the Arts of the Faculty of Architecture of the Cracow University of Technology. N. Stojak 03.2020).

Krasiczyn's cultural landscape. However, it is surrounded by anonymous and disorderly contemporary architecture (Fig. 21a and b), without any sort of urban and landscape composition, causing the entire locality to lose its cultural values. Disorderly greenery, which obscures important visual axes oriented towards and away from the complex, is also a significant problem.

The circulation layout and plot border divisions demarcate the historical plan of the market square, with a single strip of development, divided into front-facing settlement plots. This applies particularly to the former south frontage and partially to the northern one. These plots are developed in only a handful of cases, which provides potential for the revitalisation of the layout.

The residence is, of course, an exceptional work of Mannerism and is protected as a registered heritage site of the Subcarpathian Voivodeship (entry A-321 from 26.06.1968). The heritage site registry entry stipulates the protection of the castle, the Swiss house, the workhorse stables (internal building), the park, and the southern park gate. ${ }^{45}$ We can see that the registry entry does not cover the former urban complex. The residential complex is also under a second form of statutory protection. It was proclaimed a Monument to History in 2018. The protected area includes the residence, the park, the Swiss house, the workhorse stables, and the lodge, which is why it can be assumed it is identical to the scope of the heritage site registry entry. ${ }^{46}$

The municipality of Krasiczyn does not have a local spatial development plan in place, which, as a statutory form of conservation, ${ }^{47}$ could provide opportunities to protect the space of a

\footnotetext{
${ }^{45}$ Rejestr zabytków województwa podkarpackiego (Heritage site registry of the Subcarpathian Voivodeship), accessed 1 February 2020, http:// bip.wuozprzemysl.pl/index.php?id=230.

${ }^{46}$ Rozporządzenie Prezydenta Rzeczypospolitej Polskiej z dnia 20 kwietnia 2018 r. w sprawie uznania za pomnik historii "Krasiczyn_zespół zamkowo-parkowy", (Ordinance of the President of the Republic of Poland of 20 April 2018 on acknowledging "Krasiczyn_park and palace complex" as a monument of history) https://nid.pl/pl/ Informacje_ogolne/Zabytki_w_Polsce/Pomniki_historii/2018/Krasiczyn.pdf, accessed 1 February 2020.

${ }^{47}$ Obwieszczenie Marszałka Sejmu Rzeczypospolitej z dnia 3 października 2018 r. w sprawie ogłoszenia jednolitego tekstu ustawy o ochronie zabytków i opiece nad zabytkami, Dz. U. 2018, poz. 2067, Rozdział 2, Art.7. (Notice of the Marshall of the Sejm of the Republic of Poland of the 3rd of October 2018 concerning the proclamation of the codified text of the act on the protection and preservation of historical monuments, Dz. U. 2018, pos. 2067, Chapter 2, Art.7).
} 

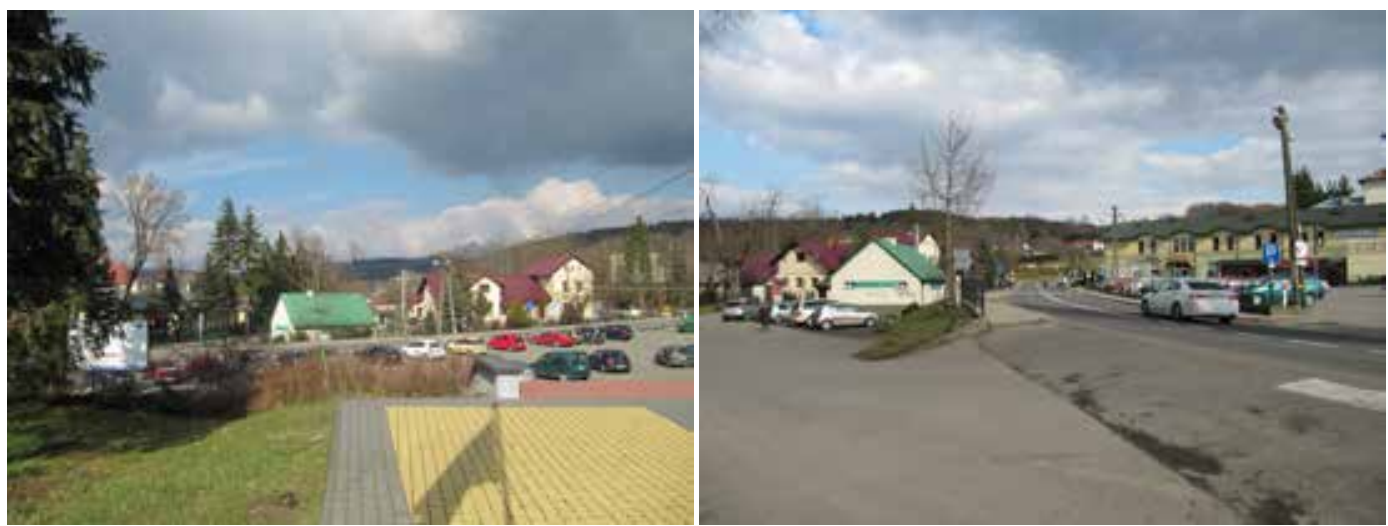

Fig. 21. a. \& b. Krasiczyn, view of the town's new centre (photograph from the collection of the Chair of the History of Architecture, Urban Planning and the Arts of the Faculty of Architecture of the Cracow University of Technology. N. Stojak 03.2020).

given city or town. The municipality does have an applicable spatial development conditions and directions study. This document defines the entire historical town-and-residence layout as being under "full conservation" and as located in a "heritage site protection zone". 48

In summary, at present, the early modern town-and-residence layout of Krasiczyn can be considered erased, and its elements, featuring different cultural values, as disjointed. Undoubtedly, there is no contemporary conservation vision that could restore the memory of the complex to the local community, even if only by signalling it.

\section{Contemporary paradigms concerning cultural value protection and urban revitalisation}

This paper was based on basic research performed from the perspective of conservation and urban planning, based on traditional research methods used in the technical sciences and artistic studies. Prior to the formulation of conclusions, it should be stated that the contemporary protection of historic cities today is no longer the domain of the axiology of conservators or urbanists. It has departed from the traditional perspective of conservation, planning, and space, and now involves the monitoring and management of social processes, wherein conservation tasks are merely an element of governance policy. Changes in identifying and evaluating elements of the urban structure appear to be following the direction of identifying intangible heritage while accounting for various stakeholder groups.

Here it would be appropriate to remind ourselves of the message of the "Warsaw Recommendation" of 1976 concerning the protection of heritage complexes, ${ }^{49}$ which indicated that, thanks to various types of value, they provide society with the living presence of the past, constituting a source of national identity. As well as cultural values, social and economic considerations - including the defining of spatial development plans together with property

\footnotetext{
${ }^{48}$ Studium uwarunkowań i kierunków zagospodarowania przestrzennego gminy Krasiczyn (Spatial development conditions and directions study for the municipality of Krasiczyn), accessed 2 February 2020, http:/ /www.krasiczyn. pl/bip/gospodarka-nieruchomosciami/planowanie-przestrzenne/599-studium-uwarunkowan-i-kierunkow-zagospodarowania-przestrzennego-gminy-krasiczyn; KUŚNIERZ-KRUPA, XIV-wieczne układy..., pp. 10-85.

${ }^{49}$ Zalecenia dotyczące ochrony zespołów zabytkowych i tradycyjnych i ich roli w życiu współczesnym (Rekomendacja Warszawska) (Recommendation concerning the Safeguarding and Contemporary Role of Historic Areas), UNESCO, Warszawa-Nairobi 1976. In: Vademecum..., pp. 61-68.
} 
owners and users- -have also become factors that justify protection. ${ }^{50}$

The first international document that focused strictly on the protection of historical cities was the Washington Charter (1987), which defined new elements that conveyed the values of historic cities. ${ }^{51}$ It stipulated that the historical character of cities is based on values that are derived from traditional, authentic elements associated with spatial composition (a plan defined by streets and plot divisions, size, scale, and development structure). Intangible (spiritual) conveyors were also acknowledged. The document also used poorly defined terms like the "interdependency" between development, greenery, and open space, between the historical and contemporary areas and the cultural environment, or the "functions" the city had in the past. ${ }^{52}$ Other documents that either amended or sanctioned changes in historic city protection doctrines include the UNESCO Vienna Memorandum (2005), which included a proposal to introduce a new heritage category: the historic urban landscape, in which strategic actions would be undertaken with the cooperation of representatives of all stakeholder groups. ${ }^{53}$ The HUL Recommendation of 2011 is an extension of this approach. ${ }^{54}$ The titular landscape is the material and intangible heritage of the city and is a form of socio-cultural and economic capital. It is also, according to Professor Bogusław Szmygin's interpretation, a form of holistic urban governance, wherein one not only protects values, but governs current socio-cultural and economic processes, ensuring sustainable development. Traditional conservation strategies are merely one of the elements of this strategy. It can of course lead to the emergence of threats to the authenticity of the material substance of heritage sites, particularly in the context of accepting the participation of all stakeholder groups, but it can also provide opportunities for a more complete diagnosis of the values of cities by using academic methods, e.g. social or economic methods, etc. The document highlights that important economic initiatives in value management include, among others, services and tourism..$^{55}$

This is of particular significance to smaller centres, where it is possible to include these values in a comprehensive manner. In so-called small cities and towns, urban values and those of the cultural landscape are interlinked, and their preservation requires particular public support. The aforementioned approach can, however, pose a threat to the authenticity of surviving urban structures and other heritage elements, as it allows them to be sacrificed in the name of sustainable development. ${ }^{56}$

\footnotetext{
${ }^{50}$ The subject of doctrinal changes in protecting historic towns was discussed by LUBOCKA-HOFFMANN, Maria. Doktryna konserwatorska a odbudowa miast. In: Studia Elblaskie, 9, 2008, pp. 241-249.

${ }^{51}$ Międzynarodowa karta ochrony miast historycznych (Charter For The Conservation Of Historic Towns And Urban Areas), ICOMOS, Toledo-Waszyngton 1987. In: Vademecum ..., pp. 91-93.

${ }^{52}$ Ibidem, Zasady i cele. See also: LUBOCKA-HOFFMANN, Doktryna..., pp. 241-249.

${ }^{53}$ Memorandum Wiedeńskie dotyczące "Dziedzictwa Światowego i Współczesnej Architektury-Zarządzania Historycznym Krajobrazem Miejskim” (Vienna Memorandum on "World Heritage and Contemporary Architecture -Managing the Historic Urban Landscape”), UNESCO, Vienna 2005, transl. K. PIOTROWSKA-NOSEK, "Ochrona Zabytków", 2005, pp. 103-106.

${ }^{54}$ LUBOCKA-HOFFMANN, Doktryna..., pp. 241-249; SZMYGIN, Bogusław. Rekomendacja o Historycznym Krajobrazie Miejskim-wdrożenie zmiany paradygmatu w ochronie miast historycznych. In: Architektura $i$ Budownictwo, 12, 2013, pp. 117-126; Zalecenie UNESCO w sprawie historycznego krajobrazu miejskiego, Paris 2011. In: Vademecum..., pp. 183-189.

${ }^{55}$ SZMYGIN, Rekomendacja..., pp. 119-124; Zalecenie UNESCO..., art. 8 and n.

${ }^{56}$ Ibidem, pp. 120-123; Zalecenie UNESCO..., art. 8 and n.
} 
K. Zimna-Kawecka - D. Kuśnierz-Krupa - M. Krupa: Heritage of (non-)existing cities...

\section{Forms of protecting historic cities in Poland}

The Polish heritage conservation system, when so-called immovable monuments (i.e. historic urban or rural layouts) are concerned, features four main forms of protection. These are the heritage registry, monument to history, the cultural park, and the provisions of local spatial development plans. $^{57}$

The decision to enact the first type of protection is made at the discretion of the voivodeship conservator of historical monuments and its consequences include obtaining their approval for any and all work and procedures undertaken within the area. The monument of history designation is a special form of protection for already-registered heritage sites or sites that form cultural parks of exceptional value. Conferring the status of a monument of history is done via an Ordinance issued by the President of Poland. It is assumed that such buildings can be presented to the UNESCO World Heritage Committee with an application to have them placed on the World Heritage Sites List. ${ }^{58}$ Cultural parks are established through Municipal Council resolutions upon approval by the voivodeship conservator of historical monuments. This form of protection is conferred upon areas with exceptional landscapes and which possess heritage sites associated with local building or settlement tradition. This is why this form of protection can be used both for an entire urban or rural layout or a part of it (e.g. the best-preserved part), but also for more extensive areas. The resolution stipulates the park's clear boundaries and the mode of protection, including prohibitions and constraints concerning spatial measures and the permissible form in which heritage structures can be used. The municipality is obligated to draft a local spatial development plan for it..$^{59}$

The fourth form of protection is the provision of local spatial development plans through consultation with the conservation office. They are formulated not only for heritage sites listed in the registry, but also for those in records kept by voivodeship conservators and municipalities, called monument records. ${ }^{60}$ Local spatial development plan provisions or land development permits must be compliant with a mandatory municipal heritage preservation programme and the spatial development conditions and directions study. ${ }^{61}$

The aforementioned conservation zones delineated in local plans or studies include: a strict conservation zone; a zone of protecting the heritage site in terms of maintaining essential elements; and cultural landscape protection zones and archaeological protection zones. ${ }^{62}$

\footnotetext{
${ }^{57}$ In the case of the last form, when there is no local spatial development plan in place, protection can be exercised through the provisions of public project permits, land development permits, road construction permits, railway construction permits, or public airport siting permits. See: Ustawa z dnia 23 lipca 2003 r. o ochronie zabytkón $i$ opiece nad zabytkami (Heritage protection and preservation act of the 23rd of July 2003, Dz.U. No. 162, pos. 1568 as amended), art. 7 .

${ }^{58}$ Among the 105 monuments of history, 22 are typical heritage sites associated with urban planning. See: Ustawa z dnia 23 lipca 2003..., art. 9, section 1-7, art. 15, section 1-4; Lista obiektów uznanych przez Prezydenta RP za Pomniki Historii (List of sites acknowledged by the President of Poland as Monuments of History, https://www.nid.pl/ pl/Informacje_ogolne/Zabytki_w_Polsce/Pomniki_historii/, accessed 4 February 2020.

${ }^{59}$ Ustawa z dnia 23 lipca $2003 \ldots$, art. 16-17.

${ }^{60}$ Ibidem, art. 18-24.

${ }^{61}$ Ibidem, art. 19, section 1-3, 20; Ustawa z dnia 27 marca 2003 r. o planowaniu i zagospodarowaniu przestrzennym (Spatial planning and development act of 27 March 2003, Dz.U. No. 80 pos. 717 as amended).

${ }^{62}$ See: WELC-JEDDRZEJEWSKA, Jolanta, et al. (elab.). Problematyka ochrony dziedzictwa kulturowego $i$ zabytków w studiach uwarunkowań $i$ kierunków zagospodarowania przestrzennego gmin oraz w miejscowych planach zagospodarowania przestrzennego, poradnik dla planistów i samorzadów lokalnych. Warsaw: Narodowy Instytut Dziedzictwa (further: NID), 2011, pp. 25-30; WITWICKI, Michał. Strefy ochrony konserwatorskiej (cechy obszarów chronionych, wyznaczenie granic ochrony, podstawowe wytyczne konserwatorskie). In: Ochrona Zabytków, 38(3-4), 1985, pp. 151-156.
} 
Detailed provisions concerning protection within each zone are drafted by the voivodeship conservator and municipalities must adapt their spatial policies accordingly.

\section{Critical analysis of conservation problems and conclusions as to the protection} of the cultural values of historic towns in Świecie and Krasiczyn

In the case of Świecie nad Wisła, the area of the historic town layout linked with the castle has remained undeveloped, which could aid in conducting wide-ranging archaeological and architectural research. Its findings could allow us to determine the original plot layout and its development, the character and spatial layout of residential buildings during the Middle Ages (and in later times), as well as the precise outline of the remaining defensive wall sections. Although the surviving structures were placed under protection (including archaeological protection), in the town's spatial development concept the area in question remains outside of the local authorities' primary field of interest despite the identification of immense cultural and natural values in documents concerning spatial management and tourist information. The focus remains fixed on the castle ruin with its observation tower as the major tourist attraction, with the measures that are taken being haphazard and deleterious to the heritage site as even the most basic archaeological and architectural research has not been performed and the reconstruction design does not account for the preservation of valuable artefacts. The use of the entire territory of the ward has also not been accounted for. Here, appropriate measures should include conducting studies of the historic town's cultural landscape and any identified values should be analysed and inspected for potential use in pursuing a policy of sustainable development.

Historical studies should be accompanied by an academic, theoretical reconstruction of the town. Utilising the lack of development and the recreational and landscape forms of use stipulated in planning guidelines (oriented towards tourist traffic which currently concentrates around the castle ruins), an attempt could be made to highlight the compositional values of the medieval urban layout and partially even those of its spatial elements (the town hall) as an archaeological park, by "extending" the wall line or marking it with greenery. The entire area would have to be given the status of a cultural park, along with a rational programme of "use" and development - the Xanten Archaeological Park could serve as an inspiration here. This way, the castle could once again be linked with the town, in a manner typical for the functioning of a Teutonic town. It would be the only case of a Teutonic town with an elongated, axial layout in the Kuyavian-Pomeranian Voivodeship, slightly resembling the layout of Malbork (the capital of the former Monastic state of the Teutonic Knights, a town linked with a castle that was placed on the UNESCO World Heritage Sites List in 1997). It would constitute not only an object of academic interest, but also a tourist destination, contributing to the proper interpretation of the HUL Recommendation and to the economic development of contemporary Świecie.

Similarly to medieval Świecie, the former layout of early modern Krasiczyn, with features of compositional town-and-residence linkages, has largely remained undeveloped. This is an opportunity for implementing a carefully planned conservation strategy in this area. The conservation measures should be backed by multi-directional academic studies, ranging from archival queries to analyses of the local spatial development plan. Ongoing archaeological studies that could allow an interdisciplinary team to formulate a programme and then a design of the revitalisation of the town's urban layout appear to be a necessary element. This conduct 
K. Zimna-Kawecka - D. Kuśnierz-Krupa - M. Krupa: Heritage of (non-)existing cities...

can provide an opportunity to place Krasiczyn under proper conservation in the future as it is currently focused solely on a fragment of the former layout, i.e. the residence. The fact that municipal authorities fail to utilise and appreciate the cultural potential of the entire complex is strange, as it can provide the municipality with urban, tourism-related, and economic development opportunities. This lack of appreciation manifests itself primarily in the form of the absence of the most fundamental planning document - the local spatial development plan. The lack of this document brings us to another important aspect. Experience has shown that the provisions of a municipality's spatial development conditions and directions study do not guarantee that land development permits (and similar documents) will share these provisions, which can result in a complete lack of heritage protection, provided that the area (or building) is not under a different statutory form of protection-with this situation applying to the historical town of Krasiczyn.

One should hope that conservation services, along with municipal authorities, will conduct their policy (on conservation, but chiefly planning) so that an actual conservation of the entire urban and residential layout of Krasiczyn will be enacted. It is also important for the framework of local law that is to crystallise in the future to foster development opportunities for the revitalisation and perhaps even recreation of the area's highly valuable urban layout that was erased over the years.

The detailed comments concerning the two analysed centres are also a point for a general discussion concerning the protection of historic cities, which, due to various events and neglect, have either lost or are in the process of losing their cultural values. The first factor that places their heritage under threat is simple ignorance of these values among the local community, government, and officials. There are no interdisciplinary urban, heritage, and landscape studies being performed and thus their potential findings cannot be applied in spatial planning. This postulate also appears in all international heritage protection documents. Oftentimes, administrators are convinced that if urban and historical studies for their cities were performed in the 1950s or 1970s, then they can be used to solve current problems. Meanwhile, theseoften excellent-academic studies were based on different historical, design, and planning assumptions in the context of a different socio-political reality of the Polish state (for instance, they often focused on medieval or early modern town centres while ignoring layers from the period of the industrial revolution, which left its mark on Poland in the 1870s).

Furthermore, the paradigms of urban heritage protection have changed as well, leading to the necessary incorporation of representatives of the social sciences into research teams. The policy of municipal authorities concerning the revitalisation of the centres they administer should account for social expectations and stimulate residents' interest in the city's values. They are typically conveyed by its material elements, including those rarely appreciated by residents (e.g. building lines or circulation layouts), but also attributes of traditional functions. These studies should first identify these conveyors and authorities should be obligated to disseminate this knowledge. Heritage conservation cannot be performed without stakeholder engagement and applying proper spatial policy in compliance with the precepts of sustainable development. 


\section{References}

\section{Literature}

ARSZYŃSKI, Marian (1980). Sztuka regionu świeckiego. In: Drieje Świecia nad Wisła i jego regionu, vol. 2, ed. JASIŃSKI, Kazimierz. Warsaw-Poznań-Toruń: Państwowe Wydawnictwo Naukowe, Towarzystwo Naukowe w Toruniu. ISBN: 8301025255.

CZAJA, Roman (elab.) (2012). Atlas historyczny miast polskich, v. 1, Prusy Królewskie i Warmia, b. 6, Świecie. Toruń: Wydawnictwo Naukowe Uniwersytetu Mikołaja Kopernika. ISBN: 9788323130369.

BIRECKI, Piotr (2014). Ewangelickie budownictwo kosscielne w Prusach Zachodnich. Toruń: Wydawnictwo Naukowe Uniwersytetu Mikołaja Kopernika. ISBN: 9788323131830.

BORZYSZKOWSKI, Józef, MIOTKA Marian (elab.) (1998). Przeniesienie miasta Świecia z doliny Wisły na wzgórze na lewym brzegu Czarnej Wody. In: Świecie. Ksiega jubileuszu 800-lecia, ed. BORZYSZKOWSKI, Józef. Świecie-Gdańsk: Urząd Miejski w Świeciu, Instytut Kaszubski, pp. 158-181. ISBN 8390813858.

DWORZECKI, Jacek, NOWICKA, Izabela, URBANEK, Andrzej, KWIATKOWSKI, Adam (2020). Protection of national heritage in the light of the applicable law and the actions provided in this area by police in Poland. In: Muzeológia a kulturne dedičstvo, 8(4), pp. 177-198. ISSN: 13392204.

EYSYMONTT, Rafał (2009). Kod genetyczny miasta. Średniowieczne miasta lokacyjne Dolnego Ślaska na tle urbanistyki Europejskiej. Wrocław: Via Nova. ISBN: 9788360544556

FRAZIK, Tomasz Józef (1968). Zamek w Krasiçzynie. Series: Zeszyt Naukowy. Architektura, 12. Kraków: Politechnika Krakowska. ISSN: 01371371.

FRAZIK, Tomasz Józef (1968). Terenowe badania architektoniczne zamku w Krasiczynie w roku 1966. In: Materiaty i Sprawozdania Rzeszonskiego Ośrodka Archeologicznego za rok 1966. Rzeszów: Muzeum Okręgowe w Rzeszowie, pp. 223-230. ISSN 01375725.

FRAZIK, Tomasz Józef (1969). Z badań nad najstarszymi dziejami zamku w Krasiczynie. In: Biuletyn Historii Sztuki, 2(31), pp. 249-254. ISSN: 00063967.

FRAZIK, Tomasz, Józef (1977). Z zagadnień rozwoju przestrzennego miasta Krasiczyna. In: Teka Komisji Urbanistyki i Architektury. Kraków: Oddział PAN w Krakowie, 11, pp. 33-42. ISNN: 00793450.

GOSZTYŁA, Marek, LICHOŁAI, Rafał (2017). Nieistniejąca zabudowa przyrynkowa w Krasiczynie. In: Journal of Civil Engineering, Environment and Arcbitecture, 64(34), pp. 151-158. ISSN: 23005130.

GRZELIŃSKA, Nina (2019). Piwnice zamku krzyżackiego w Świeciu—technika budowy i przekształcenia w świetle badań architektonicznych oraz problematyka konserwatorska, Master's thesis written at the Heritage Protection course, specialisation in conservation, under the supervision of Dr. PRARAT, Maciej, Torun, manuscript stored in the archives of the Department of Art Conservation of the NCU.

GUERQUIN, Bohdan (1974). Zamki w Polsce. Warszawa: Arkady. ISBN: 8321332390.

HORWAT, Jerzy (1985). Zarys genealogii rodu Krasickich do1717 r. In: Przemyskie zapiski bistoryczne, 3, pp. 60-68. ISSN: 08600317.

HOSAGRAHAR, Jyoti (2017). A History of Heritage Conservation in City Planning. In: The Routledge Handbook of Planning History, ed. HEIN, Carola. New York: Routledge, pp. 441454. ISBN: 9781138856981. 
K. Zimna-Kawecka - D. Kuśnierz-Krupa - M. Krupa: Heritage of (non-)existing cities...

JANSSEN, Joks, LUITEN, Eric, RENES, Hans, ROUWENDAL, Jan (2014). Heritage planning and spatial development in the Netherlands: changing policies and perspectives. In: International Journal of Heritage Studies, 20(1), pp. 1-21.

KAJZER, Leszek, KOLODZIEJSKI, Stanisław, SALM, Jan (2001). Leksykon zamków w Polsce. Warszawa: Arkady. ISBN: 8321341586.

KALINOWSKI, Wojciech (1986). Rozwój miast w Polsce. In: Zabytki urbanistyki i architektury w Polsce. Odbudowa i konserwacja, vol. 1, ed. ZIN, Wiktor. Warsaw: Arkady. ISBN: 8321332080.

KOBYLARCZYK, Justyna, KUŚNIERZ-KRUPA, Dominika (2018). Jakość środowiska mieszkaniowego a dziedzictwo kulturowe na pryykładzie wybranych miast województwa podkarpackiego. Kraków: Wydawnictwo Politechniki Krakowskiej. ISBN: 9788365991270.

KÖTZ, Gustav (1905). Die Verlegung der Stadt Schwetz aus der Weichselniederung auf die Höhen am linken Schwarzwasserufer (1830-1885). Schwetz: Büchners Buch - und Steindruckerei.

KSIAZŻEK, Mieczysław (1988). Zagadnienia genezy rozplanowania i typologii miast prywatnych XVI i XVII wieku w Południowej Małopolsce. CUT monograph no. 70. Kraków: Politechnika Krakowska. ISSN: 0860097X; 70.

KUŚNIERZ, Kazimierz (1989). Miejskie ośrodki gospodarcze wielkich latyfundiów potudniowej Polski w XVI oraz XVII wieku. CUT monograph no. 83. Kraków: Politechnika Krakowska. ISSN 0860-097X; 83

KUŚNIERZ-KRUPA, Dominika (2019). XIV-wieçne uktady urbanistyczne w Matopolsce $i$ na Podkarpaciu. Stan zachowania, ochrona $i$ rewaloryzacja. Krakow: Wydawnictwo Politechniki Krakowskiej. ISBN: 9788365991768.

KUŚNIERZ-KRUPA, Dominika (2019). Issue of protecting historic urban layouts of small towns in south-eastern Poland-on selected examples. In: IOP Conference Series: Materials Science and Engineering. IOP Publishing, 471, pp. 1-10. Online ISSN: 1757899X Print ISSN: 17578981.

KUŚNIERZ-KRUPA, Dominika, KOBYLARCZYK, Justyna, LISIŃSKA-KUŚNIERZ, Małgorzata, KRUPA, Michał, KUŚNIERZ, Kazimierz (2021). Typology of medieval urban layouts in historic Lesser Poland and their protection. In: Planning Perspectives, 36(4), pp. 847-857. ISSN: 02665433.

MALIK, Rafał (2008). Średniowieczne lokacje miejskie nad Dunajcem. Czchów. Ze studiów nad budową i kształtem miasta lokacyjnego. In: Wiadomości Konserwatorskie, 24, pp. 67-73. ISSN: 08602395.

MALIK, Rafał (2013). Skała. Uwagi na temat budowy miasta średniowiecznego w świetle najnowszych badań nad wielkością i kształtem działki lokacyjnej. In: Wiadomości Konserwatorskie, 36, pp. 46-53. ISSN: 08602395.

MOTYLEWICZ, Jerzy (1993). Miasta Ziemi Przemyskiej i Sanockiej w drugiej połowie XVII $i$ XVIII wieku. Przemyśl-Rzeszów: Południowo-Wschodni Instytut Nauk. w Przemyślu, Wyższa Szkoła Pedagogiczna w Rzeszowie. ISBN: 8390115808.

MOTYLEWICZ, Jerzy (1985). Krasiçyn w drugiej połowie XVIII w. Zarys wybranych problemów z dziejón miasta. In: Przemyskie Zapiski Historyczne. Przemyśl: Oddział Przemyski Polskiego Towarzystwa Historycznego, v. 3, pp. 99-111. ISSN: 08600317.

PROKSA, Michał (2001). Studia nad zamkami i dworami ziemi przemyskiej od potowy XIV do poczatków XVIII wieku. Przemyśl: Archiwum Państwowe w Przemyślu. ISBN: 8388172344. 
RODWELL, Dennis (2006). Managing Historic Cities. In: Journal of Architectural Conservation, 12(2), pp. 41-61. ISSN: 1355-6207.

SPLAWSKA-KORCZAK, Maria (2014). Zamek krzyżacki w Świeciu. Próba rekonstrukcji zamku wysokiego w średniowieczu. Torun: Wydawnictwo Naukowe Uniwersytetu Mikołaja Kopernika. ISBN: 9788323132479.

SPÓRNA, Tomasz, DYMITROW, Mirek, KRZYSZTOFIK, Robert (2015). Miasta zdegradowane i restytuowane w liczbach. In: DYMITROW, Mirek, KRZYSZTOFIK, Robert (eds.). Miasta zdegradowane i restytuowane w Polsce. Geneza, rozwój, problemy. Gothenburg: University of Gothenburg, School of Business Economics and Law, Department of Economy and Society - Human Geography, pp. 367-423. ISSN: 03478521; 2015:2.

SZMYGIN, Bogusław (2013). Rekomendacja o Historycznym Krajobrazie Miejskim-wdrożenie zmiany paradygmatu w ochronie miast historycznych. In: Architektura i Budownictwo, 12, pp. 117-126. ISSN: 18990665.

SZCZERBIŃSKI, Sławomir (1982). Urbanistyka miasta sprzężonego z zamkiem w Państwie Krzyżackim w Prusach na przykładzie Świecia i Reszla, Master's thesis written under the supervision of Dr. Marian ARSZYŃSKI, Institute of Monument Studies and Conservation of the NCU in Torun, 1982, manuscript stored in the archives of the Department of Art Conservation of the NCU, sign. 124.

SZMYGIN, Bogusław (ed.) (2015). Vademecum Konserwatora Zabytków. Warsaw: Polski Komitet Narodowy ICOMOS. ISBN: 9788394028046.

WITWICKI, Michał (1985). Strefy ochrony konserwatorskiej (cechy obszarów chronionych, wyznaczenie granic ochrony, podstawowe wytyczne konserwatorskie). In: Ochrona Zabytków, 38(3-4), pp. 151-156. ISSN 00298247.

WOLSKI, Krzysztof (1962). Krasiczyn—rys dziejów zamku i latyfundium krasiczyńskiego. In: Rocznik Przemyski, 9(2), pp. 301-336. ISSN: 01374168.

Legal acts

Memorandum Wiedeńskie dotyczące “Dziedzictwa Światowego i Współczesnej ArchitekturyZarządzania Historycznym Krajobrazem Miejskim” (2005). (Vienna Memorandum on "World Heritage and Contemporary Architecture-Managing the Historic Urban Landscape”), UNESCO, Vienna (transl. K. PIOTROWSKA-NOSEK, In.: Ochrona Zabytków. Warsaw: Narodowy Instytut Dziedzictwa, 2, pp. 103-106. ISSN 00298247.

Międzynarodowa karta ochrony miast historycznych (1987) (Charter For The Conservation Of Historic Towns And Urban Areas), ICOMOS, Toledo-Waszyngton, In: Vademecum Konserwatora Zabytków (2015), ed. SZMYGIN, Bogusław. Warsaw: Polski Komitet Narodowy ICOMOS, pp. 91-93. ISBN: 9788394028046.

Obwieszczenie Marszałka Sejmu Rzeczypospolitej z dnia 3 października 2018 r. w sprawie ogłoszenia jednolitego tekstu ustawy o ochronie zabytków i opiece nad zabytkami, Dz. U. 2018, poz. 2067, Rozdział 2, Art.7. (Notice of the Marshall of the Sejm of the Republic of Poland of 3 October 2018 concerning the proclamation of the codified text of the act on the protection and preservation of historical monuments, Dz. U. 2018, pos. 2067, Chapter 2, Art.7).

Rozporządzenie Prezydenta Rzeczypospolitej Polskiej z dnia 20 kwietnia 2018 r. w sprawie uznania za pomnik historii "Krasiczyn—zespół zamkowo-parkowy" (Ordinance of the President of the Republic of Poland of 20 April 2018 on acknowledging "Krasiczyn-park 
and palace complex" as a monument of history”) https://nid.pl/pl/Informacje_ogolne/ Zabytki_w_Polsce/Pomniki_historii/2018/Krasiczyn.pdf.

Ustawa z dnia 23 lipca 2003 r. o ochronie zabytków i opiece nad zabytkami (Heritage protection and preservation act of 23 July 2003, Dz. U. No. 162, pos. 1568 as amended).

Ustawa z dnia 27 marca 2003 r. o planowaniu i zagospodarowaniu przestrzennym (Spatial planning and development act of 27 March 2003, Dz. U. No. 80 pos. 717 as amended).

Zalecenia dotyczące ochrony zespołów zabytkowych i tradycyjnych i ich roli w życiu współczesnym (Rekomendacja Warszawska) (1976) (Recommendation concerning the Safeguarding and Contemporary Role of Historic Areas), UNESCO, Warszawa-Nairobi. In: Vademecum Konserwatora Zabytków (2015), ed. SZMYGIN, Bogusław. Warsaw: Polski Komitet Narodowy ICOMOS, pp. 61-68. ISBN: 9788394028046.

Zalecenie UNESCO w sprawie historycznego krajobrazu miejskiego, Paris 2011 (Recommendation on the Historic Urban Landscape, including a glossary of definitions). In: Vademecum Konserwatora Zabytków (2015), SZMYGIN, Bogusław (ed.). Warsaw: Polski Komitet Narodowy ICOMOS, pp. 183-189. ISBN: 9788394028046.

\section{Internet pages (with documentation)}

Rejestr zabytków woj. kujawsko-pomorskiego (Heritage site registry of the Kuyavian-Pomeranian Voivodeship), accessed 31 December 2019, https://www.nid.pl/pl/Informacje_ogolne/ Zabytki_w_Polsce/rejestr-zabytkow/zestawienia-zabytkow-nieruchomych

Rejestr zabytków województwa podkarpackiego (Heritage site registry of the Subcarpathian Voivodeship), accessed 1 February 2020, http://bip.wuozprzemysl.pl/index.php?id=230

Studium uwarunkowań i kierunków zagospodarowania przestrzennego gminy Świecie 2012 (Spatial development conditions and directions study for the municipality of Świecie), Appendix 4: Kierunki zagospodarowania-plan, Appendix 5: Kierunki zagospodarowania przestrzennego-plan, accessed 15 May 2019, http://bip.swiecie. eu/ ?app=uchwaly\&nid $=8734 \& y=2012$.

Studium uwarunkowań i kierunków zagospodarowania przestrzennego gminy Krasiczyn (Spatial development conditions and directions study for the municipality of Krasiczyn), accessed 2 February 2020, http://www.krasiczyn.pl/bip/gospodarka-nieruchomosciami/ planowanie-przestrzenne/599-studium-uwarunkowan-i-kierunkow-zagospodarowaniaprzestrzennego-gminy-krasiczyn. 